\title{
Controls on magmatic cycles and development of rift topography of the Manda Hararo segment (Afar, Ethiopia): Insights from cosmogenic ${ }^{3} \mathrm{He}$ investigation of landscape evolution
}

\author{
S. Medynski ${ }^{\text {a,* }}$, R. Pik ${ }^{\text {a }}$, P. Burnard ${ }^{\text {a }}$, A. Williams ${ }^{\text {a }}$, C. Vye-Brown ${ }^{\text {b }}$, D. Ferguson ${ }^{\text {c,1 }}$, P.-H. Blard ${ }^{\text {a }}$, \\ L. France ${ }^{\mathrm{a}}$, G. Yirgu ${ }^{\mathrm{d}}$, J.I. Seid ${ }^{\mathrm{e}}$, D. Ayalew ${ }^{\mathrm{d}}$, A. Calvert ${ }^{\mathrm{f}}$ \\ a CRPG, CNRS, Université de Lorraine, UMR 7358, Vandoeuvre-lès-Nancy F-54501, France \\ ${ }^{\mathrm{b}}$ British Geological Survey, Murchison House, West Mains Road, Edinburgh EH9 3LA, UK \\ ${ }^{\mathrm{c}}$ Department of Earth Sciences, University of Oxford, Oxford OXI 3AN, UK \\ d School of Earth Sciences (formerly Department of Earth Sciences), Addis Ababa University, PO Box 1176, Addis Ababa, Ethiopia \\ e Water and Mines Bureau, Afar National Regional Government, Semera, Ethiopia \\ ${ }^{\mathrm{f}}$ USGS Menlo Park, CA 94025, USA
}

\section{A R T I C L E I N F O}

\section{Article history:}

Received 24 August 2012

Received in revised form

7 February 2013

Accepted 9 February 2013

Editor: T.M. Harrison

\section{Keywords:}

${ }^{3}$ He cosmogenic

rifts

magmatic accretion

extension

\begin{abstract}
A B S T R A C T
Crustal extension at mature continental rifts and oceanic ridges occurs by a combination of normal faulting and magma injection, which interact to create rift morphology. Quantifying the relative roles of faulting and melt intrusion in accommodating extension at magmatic rifts remains difficult and requires studies at sufficient spatial and temporal scales to resolve the interaction between these processes. In this study we provide new chronological constraints based on cosmogenic exposure dating for the $\sim 100 \mathrm{kyr}$ topographic evolution of a young and active magmatic rift segment in Afar, Ethiopia. We combine structural investigations, field mapping, geochemical analysis and cosmogenic ${ }^{3} \mathrm{He}$ exposure dating of lava surfaces in order to investigate the interplay between volcanic activity and fault growth in the northern part of the axial depression, where the rift segment intersects a large stratovolcano. Our results allow us to determine the roles of the various magma reservoirs feeding this rift system and their interactions during accretion over the past $100 \mathrm{kyr}$. New age data for key lava units allow several magmatic cycles to be distinguished. Each cycle lasts 20-40 ka resulting in periods of high and low magma supply rate. The variations in magma supply rate at the segment extremity strongly affect the development of the rift depression, with the availability of melt controlling the morphological impact of faulting. Melts from different magma reservoirs feeding the segment are chemically distinct and geochemical analysis of lavas from the rift floor allows their respective contributions to maintaining magmatic accretion to be estimated. We propose that melts from the magma reservoir at the northern end of the segment contribute around one-third of the length of this portion of the segment, whereas the mid-segment reservoir is responsible for the remaining two-thirds of the segment accretion.
\end{abstract}

\section{Introduction}

Extension at continental rifts and oceanic ridges is accommodated by two main processes: normal faulting and magma injection (Hayward and Ebinger, 1996; Batiza et al., 1996; Ebinger and Casey, 2001; Carbotte et al., 2004; Wright et al., 2006; Ayele et al., 2007; Rowland et al., 2007). In a continental environment faulting is typically dominant, whereas in oceanic ridges dyke intrusion is

\footnotetext{
* Corresponding author. Tel.: +33383594242.

E-mail address: medynski@crpg.cnrs-nancy.fr (S. Medynski).

${ }^{1}$ Now at: Lamont-Doherty Earth Observatory, Columbia University, NY, USA
}

the primary mode of extension (Wright et al., 2012), controlling crustal growth and rift segmentation. However, it remains unclear how the transition between these styles of rifting occurs and specifically how faulting and dyke intrusion interact as continental rifts evolve. Testing models of rift development requires temporal constraints on these magmatic and tectonic processes; however, these are typically lacking for most rift systems: even after considerable efforts observing and sampling ocean ridges (e.g. Macdonald, 1982; Perfit and Chadwick, 1998; Colman et al., 2012), the complete spatio-temporal evolution of individual segments remains poorly documented because of their remote location. One way to assess these questions is therefore to examine how this transition happens on land in more accessible rifted areas. 


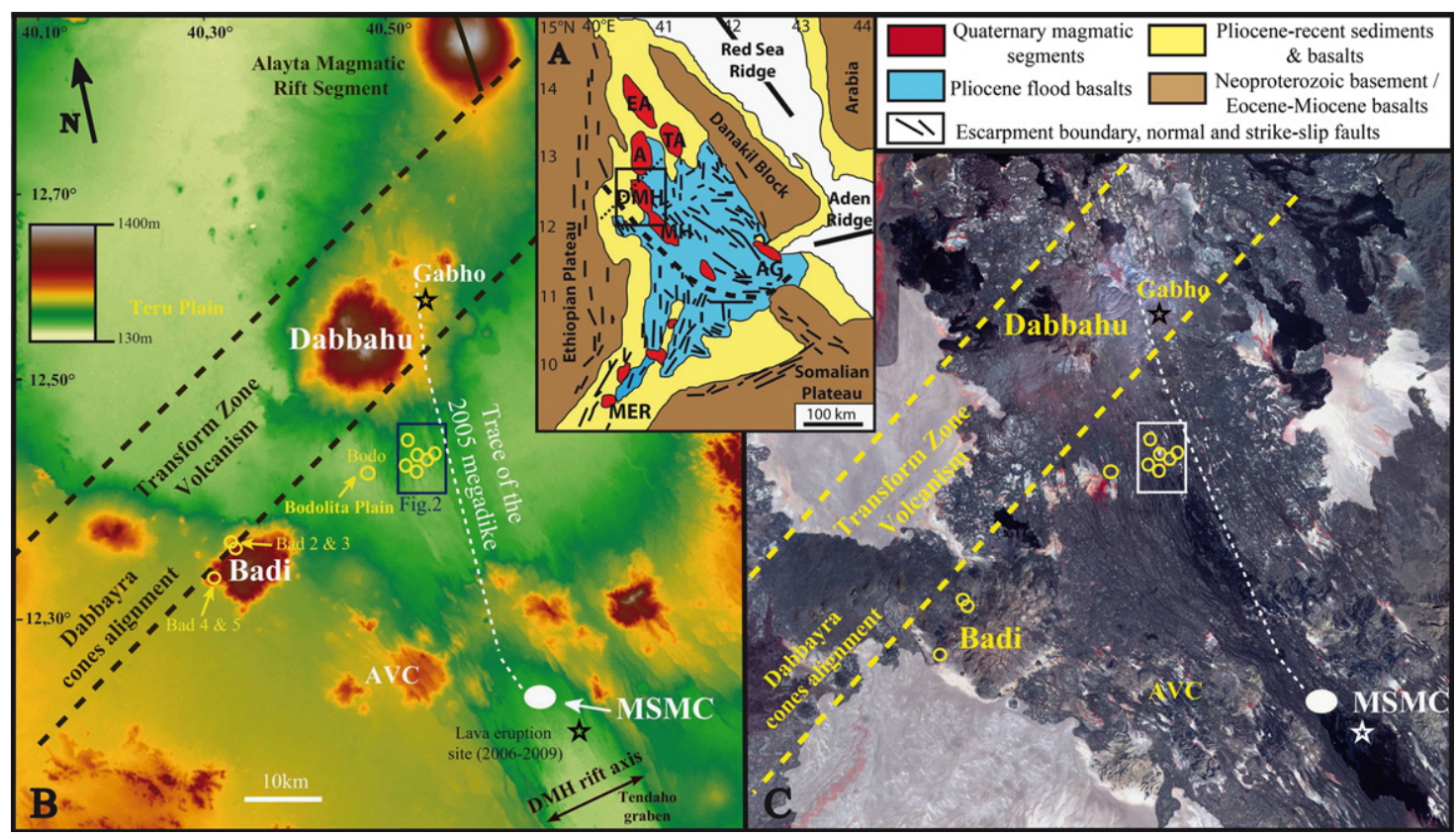

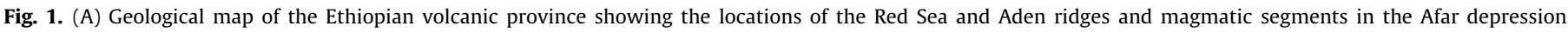

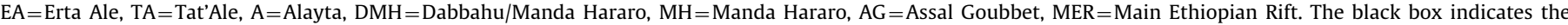

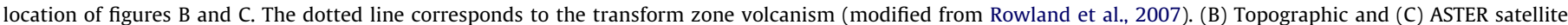

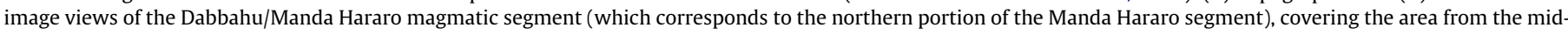

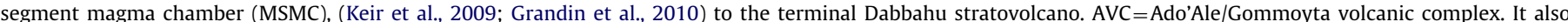

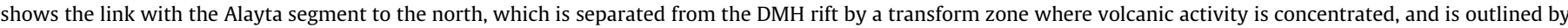

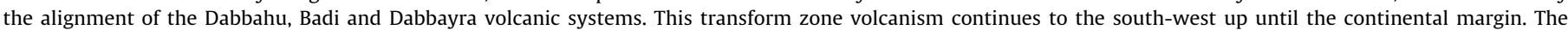

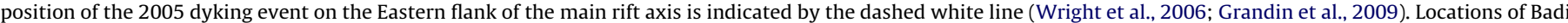
volcano and Bodolita plain samples are indicated in this figure (yellow circles); for precise locations of Yemaryugle and Gabole plain samples see Fig. 2.

The Afar region in Ethiopia is a unique example of the subaerial transition from continental to oceanic rifting. In Afar, deformation is already morphologically organised along magmatic rift segments (MRS, Hayward and Ebinger, 1996), as observed in mature oceanic ridges, but within magmatically modified continental crust (Makris and Ginzburg, 1987; Hammond et al., 2011), implying a currently incomplete continent-ocean transition (COT) (Bastow and Keir, 2011).

An additional interest in Afar resides in the major tectonicmagmatic event that the Dabbahu/Manda Hararo (DMH) segment experienced from 2005 to 2010 (Wright et al., 2006; Ebinger et al., 2010, Grandin et al., 2010). This rifting episode was the largest event of its kind to be observed and monitored with modern geophysics and satellite geodesy (e.g. Bastow et al., 2008; Barisin et al., 2009; Keir et al., 2009; Hamling et al., 2009). It involved the sequential injection of 14 dykes during this short period that were controlled by an intermittent magma supply (Wright et al., 2012). InSAR observations of inflation/deflation cycles of the rift surface (Hamling et al., 2009, Wright et al., 2006, Grandin et al., 2009) and seismic constraints on dyke propagation (Keir et al., 2009; Belachew et al., 2011) showed that intrusions injected laterally along the rift axis were fed from a melt reservoir located below the neo-volcanic zone in the rift centre. This style of magmatism is similar to crustal accretion at mid-ocean ridge spreading centres (e.g. Macdonald et al., 2001). However, it has also been shown that the rifting sequence originally started with a dyke originating from below the Dabbahu volcano (Ayele et al., 2009; Grandin et al., 2009), and triggered the following megadyke intrusion that ruptured the entire segment ( $\sim 2.5 \mathrm{~km}^{3}$ injected along $60 \mathrm{~km}$ ) (Wright et al., 2006), demonstrating that multiple magma centres simultaneously operate during a single rifting episode via a complex plumbing system.
These observations raise questions concerning long-term interactions between the principal mid-axis magma reservoir and those present at the apex of the segments along the transfer zones. In this context of moderate extension and magma production, periodic refilling of such melt pockets will partly control the morphological evolution of the neo-volcanic zone (Macdonald et al., 2001). More generally, this calls into question the role of the second-order reservoirs at the apex of the segments in maintaining segmentation during accretion processes.

The dating of land surfaces via measurements of nuclides produced by cosmic ray bombardment (i.e. Gosse and Phillips, 2001) presents a powerful tool for understanding landscape evolution. In this study, we present an extensive set of cosmogenic age constraints on the active DMH rift segment. We focus our attention on the faults and lava flows forming the current neo-volcanic zone near the northern end of the rift zone where it interacts with the Dabbahu central volcano (Barberi et al., 1974; Field et al., 2012) (Fig. 1). Combining morpho-structural investigations, mapping, major and trace elements analysis and cosmogenic ${ }^{3} \mathrm{He}$ exposure dating of lava surfaces, we investigate the interplay between volcanic activity and morphological evolution of the axial depression. The overall aim of this work is to integrate the roles of the various magma reservoirs and their interactions during accretion processes over the past $100 \mathrm{kyr}$ in order to put observations of the recent rifting episode (Wright et al., 2012) into a rift-evolution context.

\section{Geological setting: the Dabbahu Magmatic Rift Segment}

The Afar province represents the northernmost portion of the East African Rift System (EARS) where it meets the oceanic ridges of the Red Sea and Gulf of Aden, and defines a triple-junction 
(Fig. 1A). The depression is located at the heart of a long-lived volcanic province which started in northern Ethiopia by the emission of a thick pile of pre-rift continental flood basalts (CFB) 30 Myr ago (Hofmann et al., 1997; Pik et al., 1998; 1999; Ayalew et al., 2002, 2006) related to the activity of an underlying mantle plume (Marty et al., 1996; Pik et al., 2006; Bastow et al., 2008). Subsequent rifting and extension along the western Afar margin started $25 \mathrm{Myr}$ ago, soon after the CFB event (Wolfenden et al., 2005), and was accompanied by discrete and less voluminous volcanic activity up to the Pliocene (Mohr, 1967; Rooney et al., 2012). The crust and lithosphere have been significantly attenuated below the Afar depression (Tiberi et al., 2005; Bastow et al., 2010; Hammond et al., 2012) although formal breakup is not yet complete, resulting in a rift system with characteristics typical of a volcanic margin close to the COT stage (Geoffroy, 2005; Bastow and Keir, 2011, Keir et al., 2011).

Presently, extension along the Red Sea arm in the Afar depression is focused in four en-echelon MRS: Erta' Ale, Tat' Ale, Alayta and Dabbahu/Manda Hararo (Fig. 1A). The active, $\sim 60-\mathrm{km}$ long, $\sim 20-\mathrm{km}$ wide DMH magmatic rift segment (Fig. 1B) is characterised by a basaltic floor dissected by extensive normal faulting orientated NNW-SSE in the north and NW-SE in the south, with relatively moderate vertical displacements of up to $50 \mathrm{~m}$ (Rowland et al., 2007; this study) resulting in a slightly depressed neo-volcanic zone within an axial graben (Fig. 2b). The segment is surrounded by several large central volcanoes and prominent magmatic complexes, including the heavily faulted and dismantled Ado' Ale-Gommoyta differentiated volcanic complex (known as the Ado' Ale Volcanic Complex (AVC), Fig. 1). Its summit caldera demonstrates an ongoing mid-segment magmatic activity (Keir et al., 2009). The few age data that exist for this area are mainly distributed to the south and west of the segment: $\mathrm{K} / \mathrm{Ar}$ ages on basalts in the southern portion of the Manda Hararo rift (Lahitte et al., 2003a) range from 31 to 39 ka at the axis, whereas the oldest basaltic sections outside the neo-volcanic zone were dated at $\sim 100-220$ ka (Lahitte et al., 2003b). Recent Ar/Ar ages from an axisperpendicular transect immediately north of the AVC also range from $\sim 30$ to $200 \mathrm{ka}$ (Ferguson et al., 2013). The northern limit of the DMH rift is marked by the Dabbahu (also referred to as Boina in Barberi a

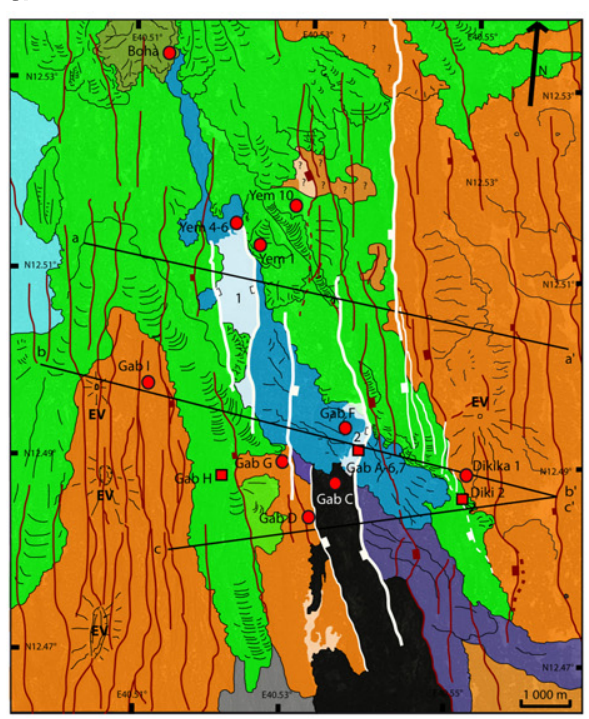

b
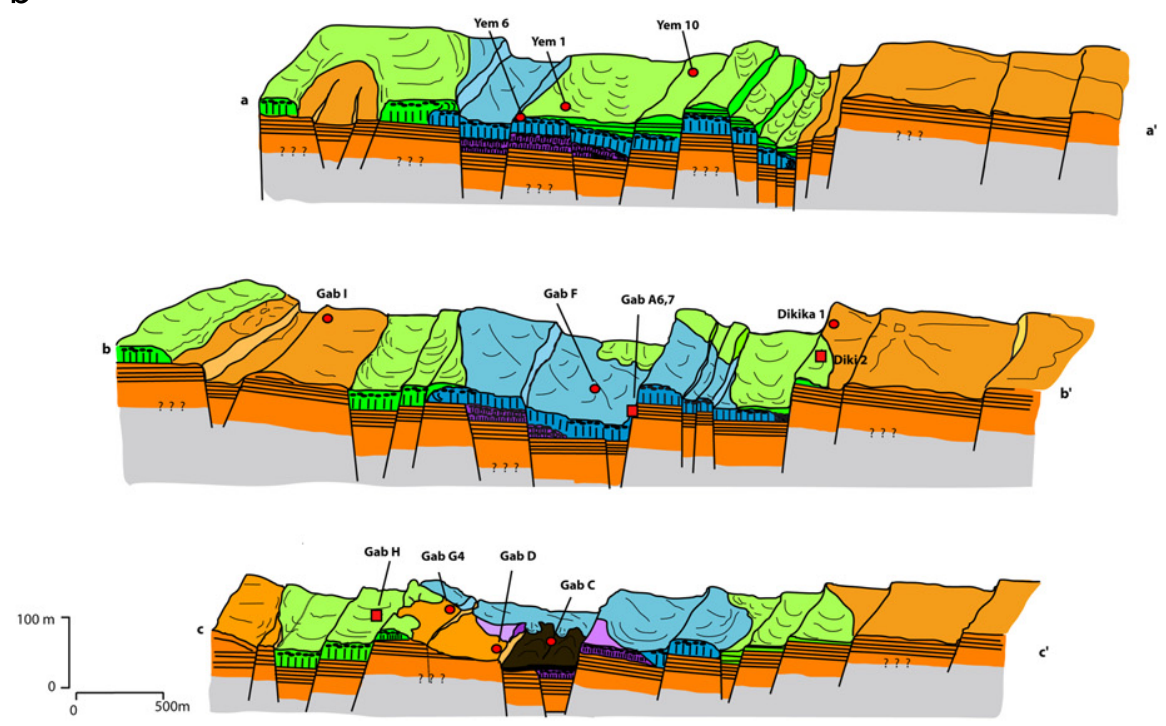

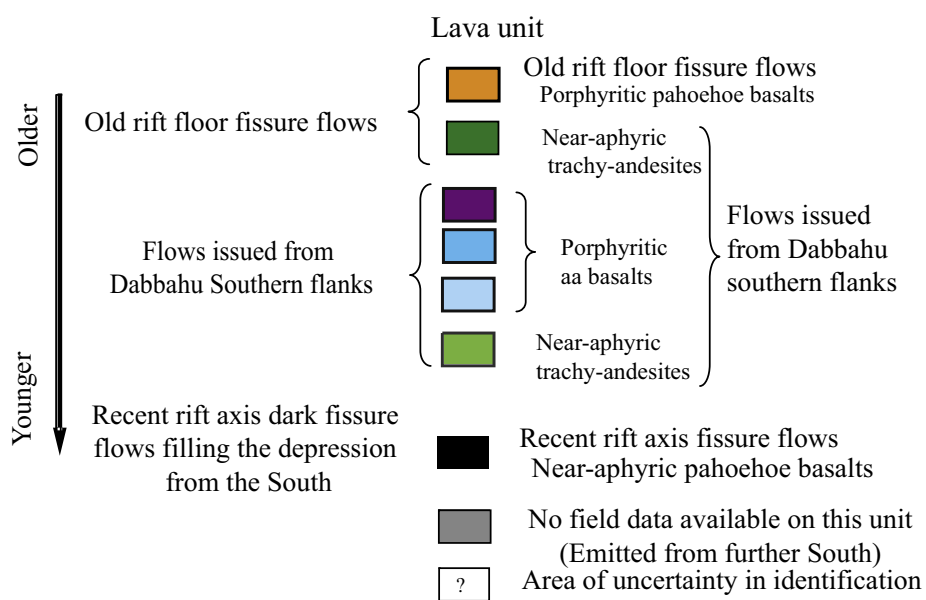

Morphological features:

Tormal fault

L Lava flow direction \& surface relief Sedimentary plain

Location names: 1: Yemaryurgle plain

2: Gabbole plain

Flow sample - for dating

Sample for chemistry only

EV Eruptive vent

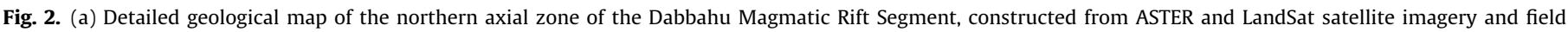

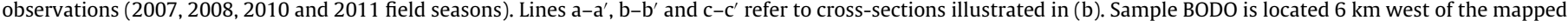

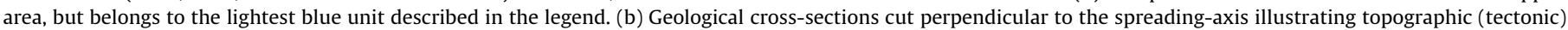

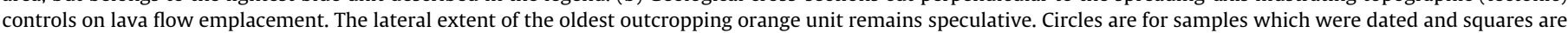

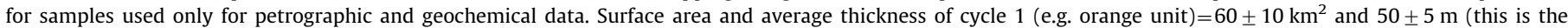

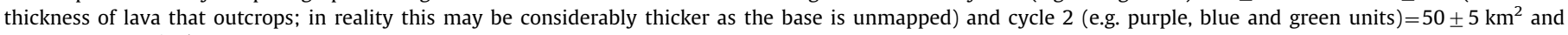
$15 \pm 5 \mathrm{~m}$ respectively. 
et al., 1974) and Gabho differentiated volcanoes, whose mafic volcanic aprons extend southwards into the neo-volcanic rift zone (Figs. 1 and 2). The oldest products sampled on Dabbahu have $\mathrm{Ar}-\mathrm{Ar}$ ages of $63.6 \pm 3 \mathrm{ka}$ (Field et al., 2013). This major central volcano located at the apex of the segment belongs to a wide chain of volcanics oriented NE-SW which includes the Badi and Dabbayra Pleistocene volcanics to the west (Lahitte et al., 2003b) and older Pliocene formations referred to as "transverse" or "marginal" volcanics to the east (Barberi et al., 1974). Along with the Dabbahu volcano they underline a transform zone that separates the DMH segment from the Alayta segment system to the north-east (Fig. 1).

The most recent volcanic activity in the DMH magmatic segment occurred during the 2005-2010 rifting event: three of the fourteen dykes injected reached the surface, producing fissure volcanism in 2007, 2009 (Ferguson et al., 2010) and 2010.

\section{Sampling details, mapping and relative chronology of lava emplacement}

We concentrate our geochronological investigation on the poorly accessible area immediately south of Dabbahu volcano, in the northern half of the segment where this central magmatic system overlaps fissural activity of the neo-volcanic zone. The study area stretches from the Bodolita plain (Fig. 1) across the MRS, to the main W-facing fault-scarps that bound the rift-zone to the east (Fig. 2). In this region, the older basaltic rift floor is highly faulted and the depression of the neo-volcanic zone has been filled by both channelized lavas flowing from the flanks of Dabbahu volcano and very recent fissural lavas erupted within the axial graben. Off-axis volcanism from Badi volcano on the western margin of the segment is also included in this study (Fig. 1) in order to compare the chemical signatures of lavas emitted in the neo-volcanic zone from the mid-segment magma chamber, with those of lavas emitted along the transform-zone and derived from reservoirs below the central volcanoes (Fig. 1).

Prior to sampling, the area was mapped at high-resolution to identify individual eruption units. Mapping at this scale enabled us to target our sampling in order to date different eruptive events and build a complete temporal record of the rift evolution.

Geological mapping was conducted using a combined approach of remote sensing image analysis and field reconnaissance (Vye et al., 2011). Analysis of topography and surface rock chemistry using Landsat, ASTER, and LiDAR imagery was conducted in ENVI ${ }^{\circledR}$ and compared with topographic maps and a LiDAR digital elevation model (DEM). Multiple images were generated and enhanced through a series of interactive techniques (false-colour-composite and histogram stretching) and statistical manipulation techniques (principal component analyses and decorrelation stretching) to increase the distinction for visual interpretation between eruptive units. Interpretation of geological linework was digitised and compiled in Arc GIS. Further visualisation of the data was conducted in GeoVisionary ${ }^{\mathrm{TM}}$ with the LiDAR DEM to provide a sense of relative stratigraphy through evaluation of the slope, relief and lava flow contacts. These interpretations were subsequently ground-proofed by targeted field studies during three campaigns in 2007, 2008 and 2010, enabling production of a geological map of the field area (Fig. 2).

Within the field area, abundant exposure and an arid environment enable mapping with limited uncertainty. Here, the spectral signature of satellite imagery reflects the rock surface and its properties (including surface roughness, composition and temperature) with little interference. The lobate nature of pāhoehoe flow fields, rubbly surfaces of weathered older lava flows, levées around 'a'ā lavas and the glassy selvages of recent lavas are all visible in the imagery and interpretation of these features has enabled the production of a high resolution map. This mapping was conducted in collaboration with the British Geological Survey, sharing methods, software and imagery that have been used to produce the new geological map of the Dabbahu-Manda Hararo Rift (Vye-Brown et al., 2012). Below we describe the individual samples taken from each of our study locations.

\subsection{Rift-axis volcanism}

Two volcanic units were identified in the rift axis region. The oldest unit of olivine and pyroxene-rich pāhoehoe lavas outcrops where the rift-axis depression has not been filled by younger shield 'a'ā-lavas (orange in Fig. 2). Samples Gab-D, Gab-G and Gab-I (Fig. 3d and e) were taken from the top of pāhoehoe flows, from the same flow field that outcrops at the axis of the depression. Gab-I was taken $50 \mathrm{~m}$ east of a volcanic cone from which this flow originates.

This unit also outcrops extensively on the eastern riftshoulder, on the top of the major scarps thus avoiding burial by later lava flow. Dikika-1 was collected from a 1-2 m-thick lava flow at the top of a $\sim 50$ m-thick pile of sheeted pāhoehoe lava flows that were emitted from a 20-30 m-high cone, $700 \mathrm{~m}$ away from the sample location (Fig. 2). Two other samples (Gab-A6 and Gab-A7) were collected for chemical analysis only, from the same unit exposed in a fault scarp $\sim 500 \mathrm{~m}$ further west in the depression. The second unit morphologically corresponds to the youngest basalts in the area. It outcrops at the rift axis in the south of the segment, and was emplaced north and south of the central Dabbahu/Manda Hararo MRS magma chamber in between axial fault-footwalls (Figs. 1 and 2). We sampled this recent lava-field on the Gabole plain. Sample Gab-C (Fig. 3f) was taken from a large (10-20 m-high) tumulus on a pāhoehoe lava flow containing scarce pyroxene microphenocrysts.

\subsection{Dabbahu central volcano: segment tip volcanism}

The compositional evolution of the Dabbahu lavas was first recognised and mapped by Barberi et al. (1974), who identified differentiation of early fissural basaltic activity to more recent pantelleritic lavas. Field et al. (2012) proposed that the most evolved liquids were stored in multiple shallow (1-5 km depth) sill-like reservoirs but that the main phase of magma differentiation/fractionation occurred at $\sim 10-15 \mathrm{~km}$ depth (Field et al., 2013). These studies were carried out on samples from the summit, northern and western flanks of the Dabbahu volcano, and describe the complexity of differentiation at Dabbahu. In contrast, here we examine only basaltic to trachyandesitic volcanism, from the south-eastern flank of the volcano where flows are issued from vents and have not been covered by subsequent (and more differentiated) lavas. These less differentiated flows exhibit typical radial-piling, and infill the DMH-rift axial de pression in this area. Two compositionally distinct units (see Section 4) can be distinguished on satellite images (green and blue in Fig. 2).

The lower unit (blue in Fig. 2), emplaced directly over older rift-floor pāhoehoe flows (orange in Fig. 2), is mainly composed of 'a'ā lava flows. Samples for cosmogenic dating were collected from three locations: the Yemaryugle (Yem-6), Gabole (Gab-F, Fig. 3c) and Bodolita (Bodo) plains. Yem-6 and Gab-F are parts of the same lava flow, used as a reference surface (Fig. 2). It was emplaced before the development of the main fault that dissects this portion of the rift, and which is vertically offset by $50-60 \mathrm{~m}$ in places (Fig. 2). This flow therefore constrains the relative chronology and interactions between the Dabbahu basaltic lava flows and the large-offset rift-axis faults that control the present day graben defining the neo-volcanic zone. 

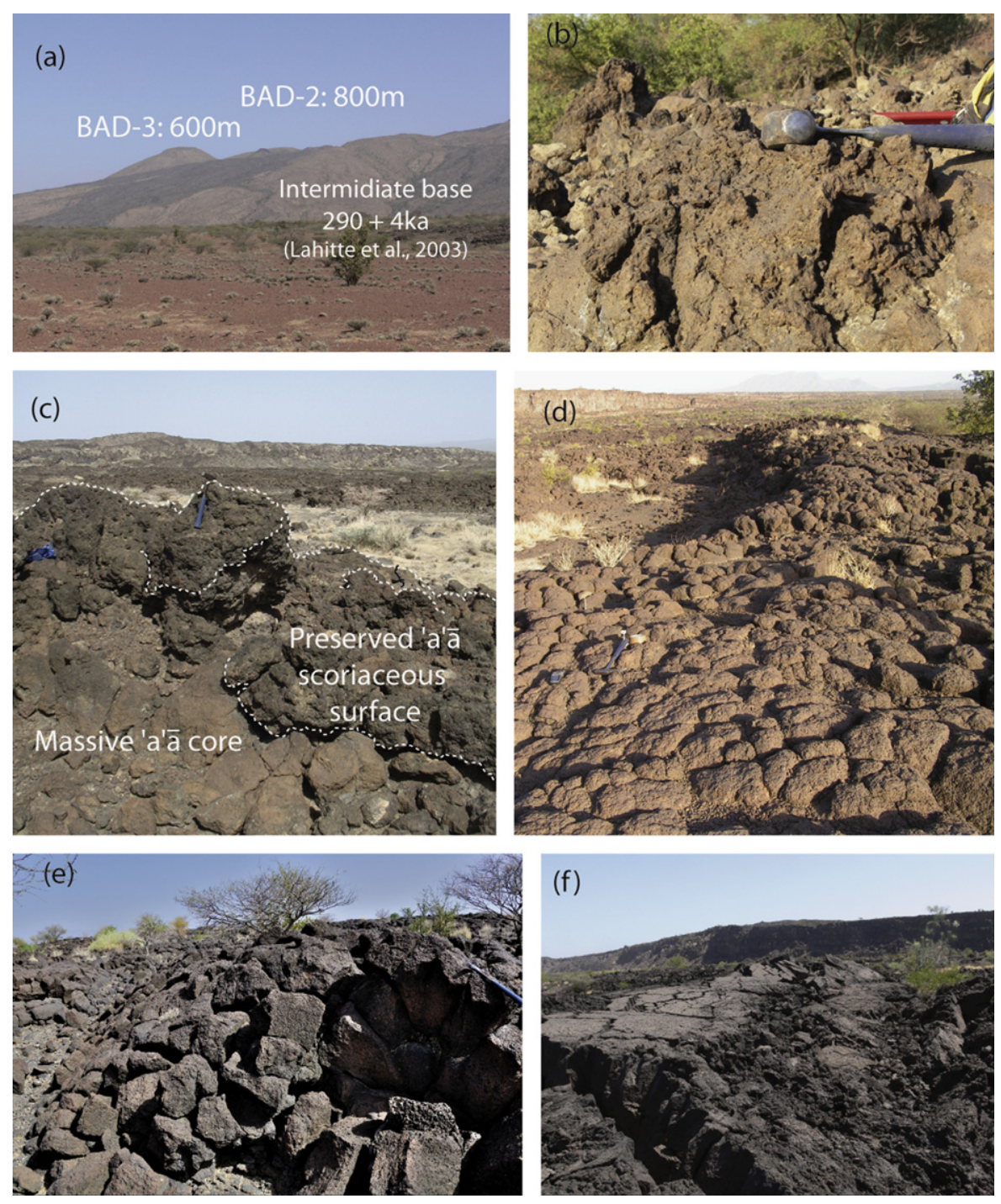

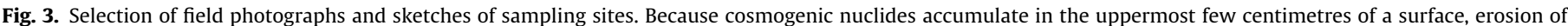

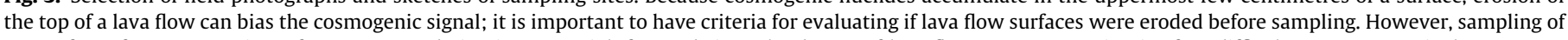

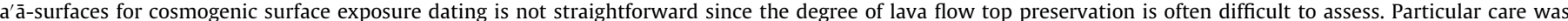

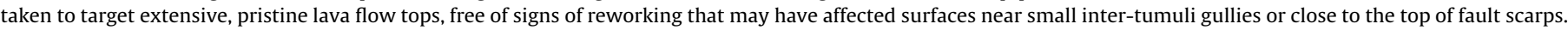

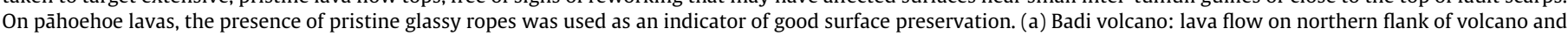

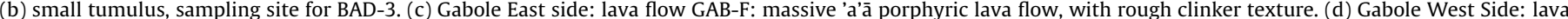

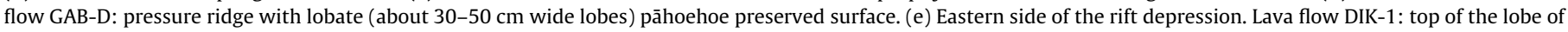
a pāhoehoe fissure-fed lava flow. (f) Southern part of the studied area. Flow GAB-C: young pāhoehoe fissure-fed lava flow.

Three samples are from the upper, more differentiated unit (green in Fig. 2, Yem-1, Yem-10 and Boha), sampled on the northern and eastern sides of the Yemaryugle plain. On the basis of mapping alone (Fig. 2), it is difficult to distinguish lava flows within the flow field. The emplacement of this unit appears to have been controlled by the older 20 -m thick porphyritic lava flow (Gab-F-blue flow in Fig. 2) on its western and southern sides, and by the major fault that displaces the Dikika pāhoehoe rift-flank volcanism on its eastern side (Fig. 2). After emplacement, the unit was dissected by propagation of the main Yemaryugle and Gabole N-S trending faults system. Two other samples (Gab-H and Dik-2) were collected for chemical analyses only on 'a'ā flows of the same flow field.

\subsection{Off-axis volcanism: Badi}

On the western side of the Dabbahu MRS, the off-axis Badi volcano consists of a suite of small basaltic parasitic cones emplaced on the flanks of an older $(290 \mathrm{kyr} \pm 4$, Lahitte et al., 2003b) silicic volcano (Fig. 1). Samples BAD-2 and BAD-3 (Fig. 3a and $b$ ) were collected at different elevations from an olivine-rich basaltic lava flow extending down the northern flank of the volcano. BAD-4 and BAD-5 were taken from the surface of a small lava flow on the western flank and exhibit an assemblage of olivine, pyroxene and plagioclase.

\section{Geochemistry and magmatic affinity of lavas}

Major and trace element concentrations were determined by ICP-OES and ICP-MS respectively, at the Service d'Analyse des Roches et des Minéraux, CRPG-Nancy, France (see Supplementary Material 1). Only the matrices of highly porphyritic cumulate samples were analysed in order to better represent the magmatic liquid. 
The samples are sub-alkaline basalts to trachyandesites. The regular variations observed in major elements (Fig. 4) are compatible with fractional crystallisation from a common parental magma, marked by enrichment in $\mathrm{Fe}+\mathrm{Ti}$, with corresponding low

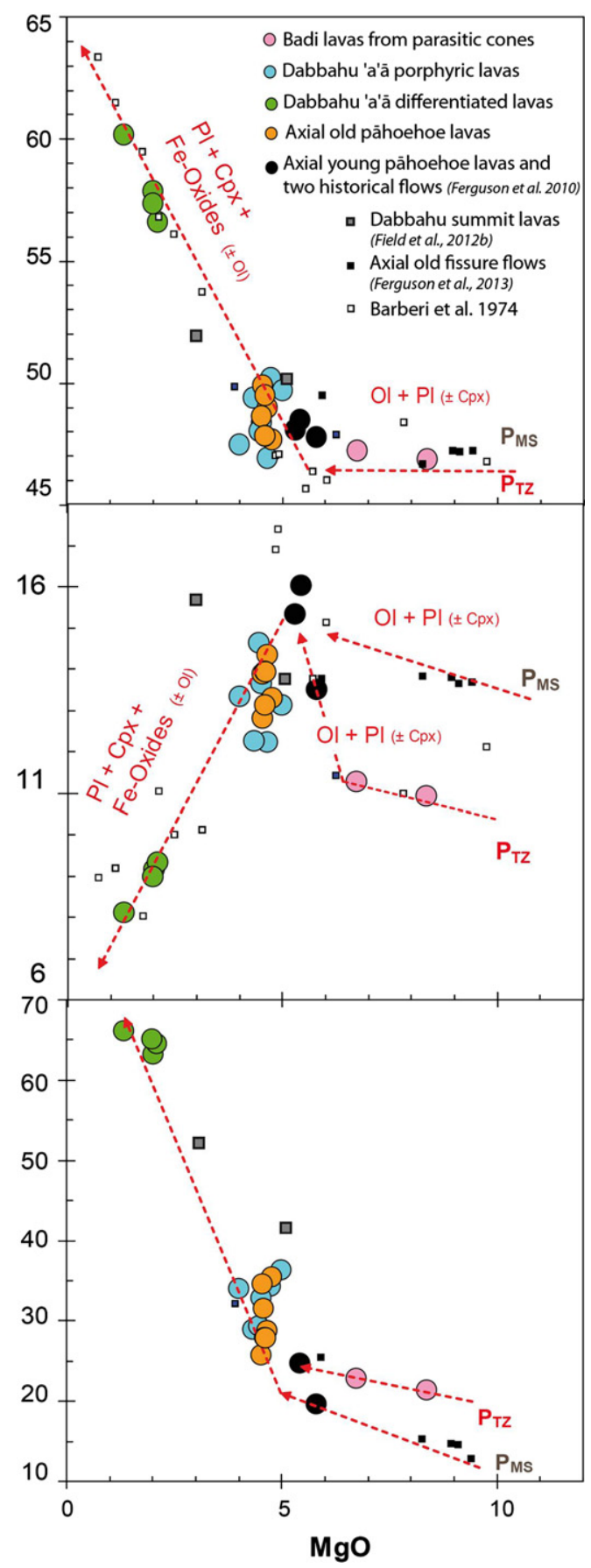

Fig. 4. Harker diagrams, showing common evolution for volcanic rocks in Afar as observed on Dabbahu (Boina) lavas by Barberi et al. (1974) although with a more restricted range due to our focused sampling area along the southern flank. MgO, $\mathrm{Fe}_{2} \mathrm{O}_{3}$, La vs. $\mathrm{SiO}_{2}$, illustrating differentiation trends for each group of lavas. The differentiation trend of Boïna/Dabbahu lavas described in Barberi et al. (1974) is also shown, as well as the composition of rift-axis pāhoehoe flows erupted in 2007 and 2009 (Ferguson et al., 2010). Small blue dots are samples of fissure-fed lava flows from the rift axis close to Gommoyta volcano (Ferguson et al., 2013). Fractionation mineral assemblages indicated on the evolution trends are indicative only. Ol=olivine, $\mathrm{Cpx}=$ clinopyroxene, $\mathrm{Pl}$ = plagioclase. A tentative composition for the primitive melts is also indicated at initiation of differentiation $(\mathrm{MgO}>10 \mathrm{wt} \%)$ for the Badi and Dabbahu transform zone volcanism $\left(P_{\mathrm{TZ}}\right)$ and for the young mid-segment volcanism ( $\left.P_{\mathrm{MS}}\right)$.
Al-content in intermediate stages related to sequential fractionation of olivine, plagioclase and clinopyroxene, typical of lowpressure crystallisation (Barberi et al., 1974; Field et al., 2012).

Interestingly, the two most primitive Badi samples also plot along this evolution trend and therefore could be compositionally related to the Dabbahu suite and its parental melt (shown on Fig. 4). Total Fe and the rare earth elements (REE) define two distinct fractionation trends for the Dabbahu/Badi group and the axial lavas, pointing towards clearly separate and compositionally different parental magmas. This is particularly clear for La (Fig. 4) in the most primitive lavas ( $\mathrm{MgO}>8 \mathrm{wt} \%$ ). The fact that the Dabbahu/Badi group falls on a different evolution line to lavas erupted from the rift axis reinforces the genetic link between the off-axis and segment-tip central volcanoes at the margins of the segment (Badi and Dabbahu) all of which belong to the transform-zone (Fig. 1) between the DMH and Alayta segments. This suggests that, while the composition of the source mantle beneath the entire region is relatively homogeneous, melts below the segment may have been generated under different degrees of partial melting, specifically affecting the REE and iron contents (and to a lesser extent the alkaline elements). A detailed investigation of such processes is beyond the scope of this paper. However, a non-modal partial melting model (Fig. 5 and Supplementary Material 2) can explain the different heavy( $\mathrm{Sm} / \mathrm{Yb}$ ratio) and light-REE ( $\mathrm{La} / \mathrm{Sm}$ ratio) fractionation of two parental magmas which can be identified below the segment. These correspond to the mid-segment magma chamber and the apex Transform Zone volcanic zone $\left(P_{\mathrm{MS}}\right.$ and $P_{\mathrm{TZ}}$ respectively in Figs. 4, 5 and 7).

\section{Cosmogenic ${ }^{3} \mathrm{He}$ exposure-dating}

Terrestrial cosmogenic nuclides (TCN) provide a robust technique for determining chronologies in a variety of geological settings (see reviews in Gosse and Phillips, 2001; Niedermann,

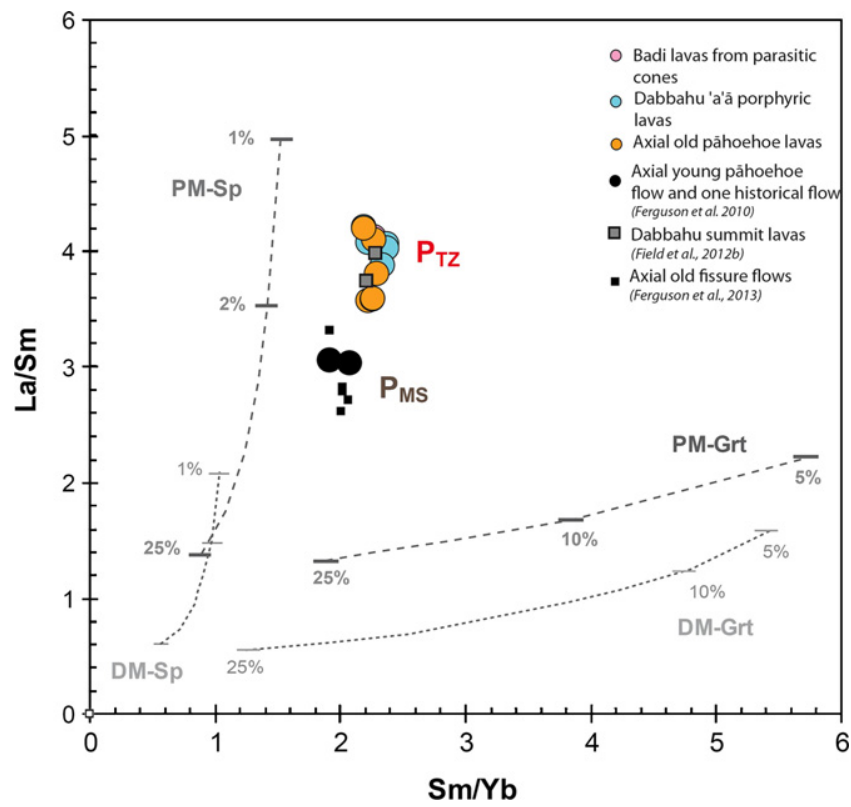

Fig. 5. La/Sm vs. Sm/Yb diagram, compiling lavas with the same degree of differentiation. Grey lines are theoretical Liquid Lines of Descent calculated for melts of Primitive Mantle (PM, Sun and McDonough, 1989), and of Depleted Mantle (DM, Workman and Hart, 2005); spinel (solid lines) and garnet (dotted lines) bearing source lithologies are modelled. Source composition, mineralogy and partition coefficients are listed in Supplementary Material 2. $P_{\mathrm{TZ}}$ and $P_{\mathrm{MS}}$ refer to the same proposed partial melt fractions as in Fig. 4 to explain the distinct signatures in REE of the different samples. 
2002; Dunai, 2010). The TCN ${ }^{3} \mathrm{He}$ has been extensively used for dating volcanic surfaces on timescales of $\sim 10^{3}$ to $>10^{6} \mathrm{yr}$ (e.g. Kurz, 1986; Kurz et al., 1990, Kurz and Geist, 1999; Blard et al., 2005; Fenton et al., 2009; Margerison et al., 2004; Foeken et al., 2009; Schimmelpfennig et al., 2011a,b) and the low rainfall and erosion in Afar are ideal conditions for TCN exposure dating as full preservation of lava surfaces is required (Gosse and Phillips, 2001).

Exposure dating provides two kinds of geomorphological information. First, the method allows the emplacement of individual lava flows to be dated. Second, it can be used to constrain the cessation of major volcanic episodes. In topographic depressions, where younger lava flows shield underlying older lava surfaces from further cosmic-ray exposure, it is not possible to use the TCN technique for dating buried lavas within a lava pile. Therefore, for the older pāhoehoe lavas which outcrop in the axial rift zone, the ages of the lava flow on top represent the cessation of an eruptive period. In contrast, on the slopes of Badi and Dabbahu, the lateral emplacement of 'a'ā lavas, unshielded by later lava flows (Fig. 2)

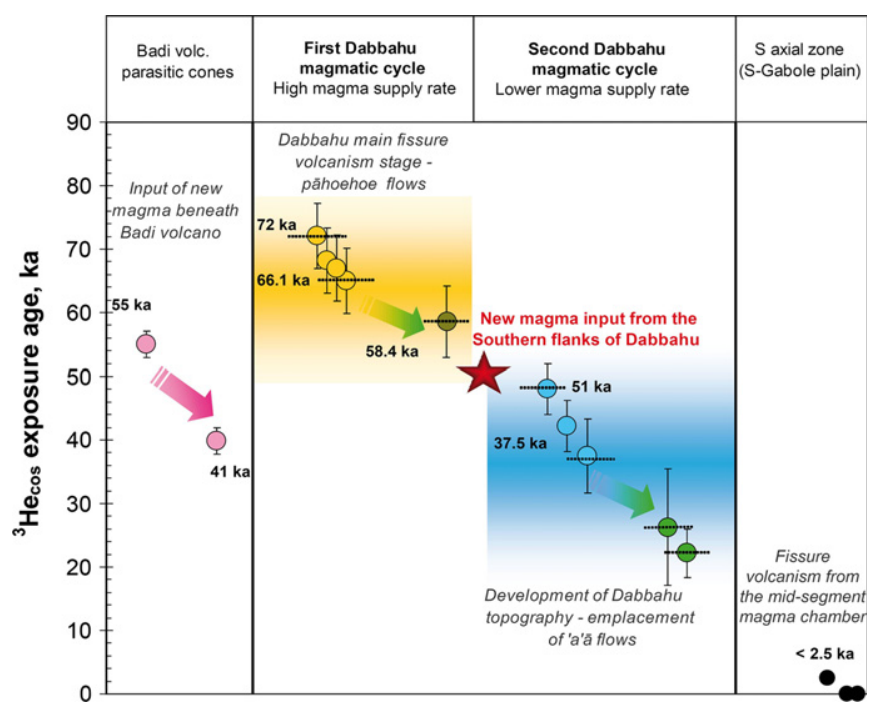

Fig. 6. Cosmogenic ${ }^{3} \mathrm{He}$ ages and summary of the chronology of flow emplacement along the northern DMH rift portion. The colour code is the same as for the geological map in Fig. 2. allows dating and documentation of discrete and more continuous eruptive events.

\subsection{Analytical techniques and exposure age calculations}

Helium extractions and isotope measurements were carried out at the noble gas laboratory at CRPG (Nancy, France) using Helix SFT and Helix MC mass spectrometers. Internal crosscalibrations of the two mass spectrometers and purification lines were made using the HESJ Helium gas standard (Matsuda et al., 2002 ), which has a ${ }^{3} \mathrm{He} /{ }^{4} \mathrm{He}$ of $20.63 \pm 0.10 \mathrm{R} / R_{A}$. Measurements of the CRONUS pyroxene He standard, "P", yielded ${ }^{3} \mathrm{He}_{c}$ concentrations of $4.95 \pm 0.1 \times 10^{9}$ at $\mathrm{g}^{-1}(n=6)$. Details of the sample preparation, gas extraction methods and treatment of analytical data at CRPG are detailed in the supplementary information (Supplementary Material 3).

Assuming zero erosion and constant exposure without burial, cosmogenic ages $T_{E}$ (a) are then calculated from the ${ }^{3} \mathrm{He}_{c}$ concentrations, $\mathrm{N}$ (atoms $\mathrm{g}^{-1}$ ), by

$T_{E}=N / P_{3}$

where $P_{3}$ is the local ${ }^{3} \mathrm{He}_{c}$ production rate (atoms $\mathrm{g}^{-1} \mathrm{a}^{-1}$ ). In the absence of a local production rate calibration, we used $P_{3}=120 \pm 9$ atoms $g^{-1} \mathrm{a}^{-1}$. This value is a global average production rate calculated from the compilation in Goehring et al. (2010) (Table 2). Because production of TCN varies with sample location, $P_{3}$ must be scaled to the elevation and latitude of the sampling site. We calculated this scaling factor using the equations of Stone (2000) (adapted from Lal, 1991) and a standard atmosphere.

\subsection{Validity of calculated exposure ages}

For all samples analysed here (Table 2), cogenetic olivines and pyroxenes yield indistinguishable exposure ages ( $<5 \%$ discrepancy between aliquots) supporting the use of a common production rate for olivine and pyroxene. Where multiple aliquots of the same sample were available, the mean exposure age was used; where several samples were analysed from a single surface, the oldest sample is assumed to be the most representative of the age of the lava (only Badi samples showed a > 5\% discrepancy between samples from different locations within the same lava flow) because erosion, shielding, or vegetation cover will result in underestimation of the true exposure age (Gosse and Phillips, 2001).

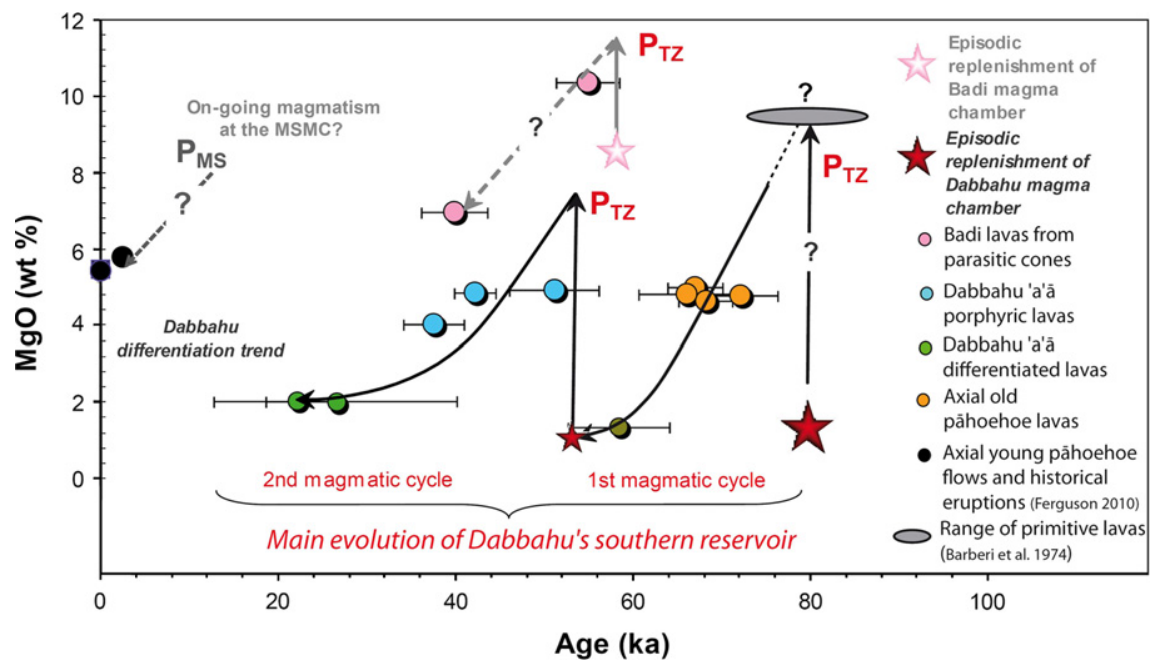

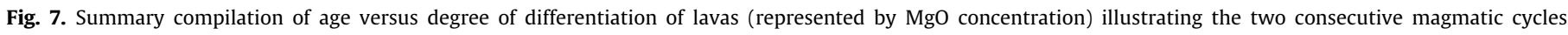

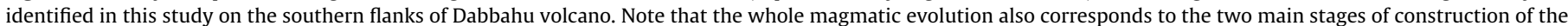
Dabbahu volcano. The colour code is the same as for the geological map in Fig. 2. 
Table 1

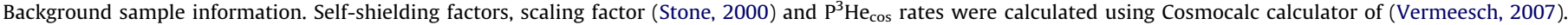
Samples were orientated in the field but no topographic-shielding corrections or corrections for self-shielding based on surface geometry were required.

\begin{tabular}{|c|c|c|c|c|c|c|c|c|c|c|}
\hline Sample & $\begin{array}{l}\text { Altitude } \\
(\mathrm{m})\end{array}$ & $\begin{array}{l}\text { Latitude } \\
\left({ }^{\circ} \mathrm{N}\right)\end{array}$ & $\begin{array}{l}\text { Longitude } \\
\left({ }^{\circ} \mathrm{E}\right)\end{array}$ & Lava morphology & Petrology & $\begin{array}{l}\text { Sample } \\
\text { thickness } \\
(\mathrm{cm})\end{array}$ & $\begin{array}{l}\text { Depth } \\
\text { correction }\end{array}$ & $\begin{array}{l}\text { Stone scaling } \\
\text { factor }\end{array}$ & $\begin{array}{l}\text { Local } \mathbf{P}^{3} \mathrm{He}_{\text {cos }} \\
\text { at } \mathrm{g}^{-1} \mathrm{yr}^{-1}\end{array}$ & \pm \\
\hline \multicolumn{11}{|c|}{ Badi parasitic cone flows } \\
\hline BAD $2 \mathrm{~A}$ & 800 & 12.41115 & 40.35053 & 'A'ā flow & Ol \& Cpx & 8 & 0.94 & 1.13 & 127 & 10 \\
\hline BAD 2B & 800 & 12.41115 & 40.35053 & ‘A'ā flow & phenocryst rich & 8 & 0.94 & 1.13 & 127 & 10 \\
\hline BAD 3A & 618 & 12.41407 & 40.34775 & 'A'ā flow & $\mathrm{Ol} \& \mathrm{Cpx}$ & 8 & 0.94 & 0.99 & 111 & 9 \\
\hline BAD 3B & 600 & 12.41407 & 40.34775 & 'A'ā flow & phenocryst rich & 9 & 0.93 & 0.97 & 108 & 8 \\
\hline BAD 4 & 650 & 12.38027 & 40.32248 & 'A'ā flow & Ol \& Cpx & 4.5 & 0.96 & 1.01 & 116 & 9 \\
\hline BAD 5 & 650 & 12.38027 & 40.32248 & 'A'ā flow & phenocryst rich & 6.5 & 0.95 & 1.01 & 115 & 9 \\
\hline \multicolumn{11}{|c|}{ Dabbahu southern flank lavas } \\
\hline GAB D4 & 400 & 12.43203 & 40.53404 & Pāhoehoe flow & $\begin{array}{l}\text { Ol \& Cpx } \\
\text { phenocryst rich }\end{array}$ & 5 & 0.96 & 0.84 & 96 & 8 \\
\hline GAB I & 461 & 12.49828 & 40.51400 & Pāhoehoe flow & $\begin{array}{l}\text { Ol \& Cpx } \\
\text { phenocryst rich }\end{array}$ & 5 & 0.96 & 0.88 & 101 & 8 \\
\hline GAB G4 & 409 & 12.29262 & 40.31518 & 'A'ā flow & $\begin{array}{l}\text { Ol \& Cpx } \\
\text { phenocryst rich }\end{array}$ & 5 & 0.96 & 0.84 & 97 & 8 \\
\hline ВОНА & 495 & 12.31485 & 40.30503 & 'A'ā flow & Rare Cpx \& Ol & 4 & 0.97 & 0.90 & 104 & 8 \\
\hline GAB F & 385 & 12.29327 & 40.32989 & 'A'ā flow & $\begin{array}{l}\text { Cumulative } \mathrm{Ol} \& \mathrm{Cpx} \\
\text { phenocryst rich }\end{array}$ & 2.7 & 0.98 & 0.82 & 97 & 8 \\
\hline YEM 6 & 432 & 12.51344 & 40.52374 & 'A'ā flow & $\begin{array}{l}\text { Cumulative Ol \& Cpx } \\
\text { phenocryst rich }\end{array}$ & 5 & 0.96 & 0.86 & 99 & 8 \\
\hline BODO & 444 & 12.51272 & 40.48839 & 'A'à flow & $\begin{array}{l}\text { Cumulative } \mathrm{Ol} \& \mathrm{Cpx} \\
\text { phenocryst rich }\end{array}$ & 4 & 0.97 & 0.86 & 101 & 8 \\
\hline YEM 1 & 454 & 12.51309 & 40.52467 & 'A'ā flow & Rare Cpx \& Ol & 5 & 0.96 & 0.87 & 100 & 8 \\
\hline YEM 10 & 458 & 12.30440 & 40.32139 & Pāhoehoe flow & Rare Cpx \& Ol & 10.5 & 0.92 & 0.87 & 96 & 8 \\
\hline \multicolumn{11}{|c|}{ Dabbahu Easternmost flow_shoulder of the depression } \\
\hline DIKIKA 1 & 435 & 12.29219 & 40.32593 & Pāhoehoe flow & $\begin{array}{l}\text { Ol \& Cpx } \\
\text { phenocryst rich }\end{array}$ & 6.2 & 0.95 & 0.86 & 98 & 8 \\
\hline \multicolumn{11}{|c|}{ Southern part of the studied area-young axial fissure flow } \\
\hline GAB C3 & 384 & 12.48327 & 40.53537 & Pāhoehoe flow & Rare Cpx & 5 & 0.96 & 0.83 & 95 & 7 \\
\hline
\end{tabular}

The method assumes constant elevation for each sampling site. The northern part of the rift axis has maximum vertical offsets of 50-70 m, corresponding to maximum $P_{3}$ variations of $5-6 \%$, therefore the assumption of constant elevation is valid (see Supplementary Material 5) and does not exceed typical analytical uncertainties.

The errors and uncertainties reported here take into account associated analytical errors but not uncertainties in $P_{3}$ calibration, scaling factors or elevation variations. Variations in $P_{3}$ due to the Earth's magnetic field could reduce ${ }^{3} \mathrm{He}_{c}$ surface exposure ages by between $3 \%$ and $17 \%$ (see Supplementary Material 6), for lava flows of 20 and $70 \mathrm{ka}$, respectively (this correction factor is given in Table 1). Similarly, the use of an alternative SLHL $P_{3}$ or scaling method could change exposure ages by up to $10 \%$, but it is important to note that the relative exposure ages would remain unchanged and that the sequence of events proposed in the present work would also remain the same.

In order to assess the validity and accuracy of our ages and $P_{3}$ values, two lava units included in this study were also dated using ${ }^{40} \mathrm{Ar} /{ }^{39} \mathrm{Ar}$ geochronology at the USGS Ar lab, Menlo Park, CA (Ferguson et al., 2013). For these lavas (GAB-D and GAB-F), coexisting phenocrysts and groundmass were analysed for ${ }^{3} \mathrm{He}$ and ${ }^{40} \mathrm{Ar} /{ }^{39} \mathrm{Ar}$ respectively. ${ }^{40} \mathrm{Ar} /{ }^{39} \mathrm{Ar}$ age-spectra and plateaux for these samples are shown in Supp. Material 6 and demonstrate excellent agreement between the two techniques (GAB-D: Age $\left({ }^{3} \mathrm{He}\right)=72.1 \pm 4.3 \mathrm{ka} ; \mathrm{Age}\left({ }^{40} \mathrm{Ar} /{ }^{39} \mathrm{Ar}\right)=69.3 \pm 7.5 \mathrm{ka}$ and $\mathrm{GAB}-\mathrm{F}$ : Age $\left({ }^{3} \mathrm{He}\right)=51.1 \pm 5 \mathrm{ka}$; Age $\left.\left({ }^{40} \mathrm{Ar} /{ }^{39} \mathrm{Ar}\right)=56.1 \pm 1 \mathrm{ka}\right)$.

\subsection{Volcanic stratigraphy}

The surface exposure ages for the northern Dabbahu segment lava-flows range from $<2 \mathrm{ka}$ (Gab-C3) to $72.1 \pm 4.3 \mathrm{ka}$ (Gab-D) (Table 2). The volcanic stratigraphy established on the basis of these results is summarised in Table 2 and Fig. 6.

\subsubsection{Old rift-floor formation}

The earliest phase of volcanic activity observed is the pāhoehoe lava flow unit (samples Gab-D, Gab-G, Gab-I and Dik-1; orange in Fig. 2). The ages range from $72.1 \pm 4.3 \mathrm{ka}(\mathrm{Gab}-\mathrm{D})$ to $\mathbf{6 6 . 1} \pm 5.4 \mathrm{ka}$ (Gab-I) on the Gabole Plain. The consistency of ages along the DMH rift axis confirms that this flow field results from a single emplacement of basaltic fissure-fed pāhoehoe lava. The sparse outcrops in the axial depression are likely due to infilling of the northern portion of the segment by subsequent lava flows originating from Dabbahu flank eruptions (Fig. 2A) and younger riftaxis eruptions. Where exposed in fault-scarps, the lava-pile associated with the old fissure unit becomes 11-m thick close to Gab-I and 50-m thick close to Dik-1, but the whole unit may be significantly thicker (Fig. 2B). The distribution of the older lava 
Table 2

Helium data and cosmogenic exposure ages.

\begin{tabular}{|c|c|c|c|c|c|c|c|c|c|c|c|c|c|c|c|c|c|}
\hline Sample & Phase $^{(a)}$ & $\begin{array}{l}\text { Magmatic } \\
{ }^{3} \mathrm{He}^{4}{ }^{4} \mathrm{He}^{(\mathrm{b})} \\
(\mathrm{R} / \mathrm{Ra})\end{array}$ & \pm & $\begin{array}{l}{ }^{4} \mathrm{He}_{\text {fusion }} \\
\left(10^{11} \mathrm{at} \mathrm{g}^{-1}\right)\end{array}$ & \pm & $\begin{array}{l}{ }^{3} \mathrm{He}_{\text {fusion }} \\
\left(10^{6} \text { at. }{ }^{-1}\right)\end{array}$ & \pm & $\begin{array}{l}\left({ }^{3} \mathrm{He} /{ }^{4} \mathrm{He}\right)_{\text {fusion }} \\
\mathrm{R} / \mathrm{Ra}\end{array}$ & \pm & R factor ${ }^{(c)}$ & $\begin{array}{l}{ }^{3} \mathrm{He} \cos ^{(\mathrm{d})} \\
\left(10^{6} \text { at. } \mathrm{g}^{-1}\right)\end{array}$ & \pm & $\begin{array}{l}\text { Minimum } \\
\text { exposure age } \\
\text { kyrs }\end{array}$ & \pm & $\begin{array}{l}\text { Flow exposure } \\
\text { age(e) } \\
\text { kyrs }\end{array}$ & \pm & $\begin{array}{l}\text { Paleomag. } \\
\text { corr. Factor }\end{array}$ \\
\hline Bad-2A \#1 & Olivine & 11.4 & 0.3 & 2.59 & 0.011 & 10.81 & 0.51 & 30.1 & 1.4 & 0.99 & 6.77 & 0.52 & 53.2 & 4.1 & - & & \\
\hline Bad-2A \#2 & Olivine & 11.4 & 0.3 & 6.27 & 0.004 & 16.56 & 0.81 & 19.1 & 0.9 & 0.99 & 6.69 & 0.85 & 52.6 & 6.7 & - & & \\
\hline Bad-2B & Olivine & 11.4 & 0.3 & 1.84 & 0.005 & 10.35 & 0.30 & 40.7 & 1.2 & 0.99 & 7.52 & 0.31 & 59.0 & 2.4 & 54.9 & 3.6 & 1.13 \\
\hline Bad-3A & Olivine & 11.4 & 0.3 & 5.56 & 0.008 & 14.49 & 0.34 & 18.8 & 0.4 & 0.99 & 5.74 & 0.41 & 51.8 & 3.7 & & & \\
\hline Bad-3B & Olivine & 11.4 & 0.3 & 3.17 & 0.004 & 10.67 & 0.32 & 24.3 & 0.7 & 0.99 & 5.71 & 0.35 & 52.6 & 3.2 & & & \\
\hline Bad-5 \#1 & Pyroxene & 10.5 & 0.9 & 2.33 & 0.003 & 7.54 & 0.16 & 23.4 & 0.5 & 0.98 & 4.27 & 0.32 & 37.1 & 2.8 & & & \\
\hline Bad-5 \#2 & Olivine & 10.5 & 0.9 & 3.80 & 0.11 & 4.94 & 0.23 & 93.84 & 28.49 & 0.99 & 4.45 & 0.29 & 38.73 & 2.5 & & & \\
\hline Bad-5 \#3 & Olivine & 10.5 & 0.9 & 1.34 & 0.003 & 6.21 & 0.15 & 33.6 & 0.8 & 0.99 & 4.34 & 0.22 & 37.7 & 1.9 & & & \\
\hline Bad-4 \#1 & Pyroxene & 10.5 & 0.9 & 2.24 & 0.003 & 7.71 & 0.41 & 24.8 & 1.3 & 0.98 & 4.57 & 0.49 & 39.3 & 4.2 & - & & \\
\hline Bad-4 \#2 & Pyroxene & 10.5 & 0.9 & 1.53 & 0.006 & 6.85 & 0.68 & 32.3 & 3.2 & 0.98 & 4.70 & 0.70 & 40.4 & 6.0 & 39.8 & 3.7 & 1.08 \\
\hline Gab-D4 \#1 & Pyroxene & 13.3 & 1.6 & 0.23 & 0.003 & 7.14 & 0.65 & 224.0 & 20.7 & 0.96 & 7.01 & 0.65 & 72.9 & 6.8 & - & & \\
\hline Gab-D4 \#2 & Olivine & 13.3 & 1.6 & 0.80 & 0.007 & 8.35 & 1.08 & 75.4 & 9.8 & 0.97 & 7.07 & 1.10 & 73.5 & 11.4 & - & & \\
\hline Gab-D4 \#3 & Olivine & 13.3 & 1.6 & 0.45 & 0.004 & 7.56 & 0.98 & 122.3 & 16.0 & 0.97 & 6.93 & 0.99 & 72.0 & 10.3 & - & & \\
\hline Gab-D4 \#4 & Olivine & 13.3 & 1.6 & 0.74 & 0.001 & 7.91 & 0.30 & 77.1 & 2.9 & 0.97 & 6.73 & 0.34 & 69.9 & 3.5 & 72.1 & 4.3 & 1.17 \\
\hline Dikika \#1 & Olivine & 8.4 & 0.8 & 0.27 & 0.005 & 7.06 & 0.37 & 185.56 & 10.40 & 0.96 & 7.00 & 0.37 & 71.7 & 3.8 & - & & \\
\hline Dikika \#2 & Olivine & 8.4 & 0.8 & 1.03 & 0.020 & 7.33 & 0.44 & 51.30 & 3.23 & 0.96 & 6.36 & 0.45 & 65.1 & 4.6 & - & & \\
\hline Dikika \#3 & Olivine & 8.4 & 0.8 & 1.43 & 0.029 & 8.04 & 0.45 & 40.65 & 2.44 & 0.96 & 6.62 & 0.48 & 67.8 & 4.9 & 68.2 & 3.3 & 1.16 \\
\hline Gab-G4 \#1 & Olivine & 10.0 & 2.6 & 4.38 & 0.011 & 6.51 & 0.36 & 107.25 & 6.50 & 0.96 & 6.16 & 0.39 & 63.72 & 4.1 & - & & \\
\hline Gab-G4 \#2 & Pyroxene & 5.7 & 0.7 & 3.93 & 0.006 & 6.60 & 0.35 & 121.14 & 6.70 & 0.97 & 6.47 & 0.36 & 66.9 & 3.7 & - & & \\
\hline Gab-G4 \#3 & Pyroxene & 5.7 & 0.7 & 2.73 & 0.012 & 6.56 & 0.35 & 173.50 & 12.20 & 0.97 & 6.53 & 0.36 & 67.5 & 3.7 & - & & \\
\hline Gab-G4 \#4 & Pyroxene & 5.7 & 0.7 & 6.35 & 0.025 & 7.41 & 0.43 & 85.50 & 5.90 & 0.97 & 7.11 & 0.43 & 73.5 & 4.5 & 67.9 & 4.1 & 1.16 \\
\hline Gab-I \#1 & Olivine* & $10.9^{*}$ & $2^{*}$ & 2.24 & 0.07 & 6.40 & 0.52 & 206.49 & 18.00 & 0.98 & 6.20 & 0.53 & 64.11 & 5.43 & - & & \\
\hline Gab-I \#2 & Olivine & $10.9^{*}$ & $2^{*}$ & 1.54 & 0.14 & 6.66 & 0.90 & 311.91 & 50.55 & 0.98 & 6.58 & 0.90 & 68.00 & 9.34 & 66.1 & 5.4 & 1.16 \\
\hline Boha \#1 & Pyroxene & 5.0 & 0.6 & 0.73 & 0.02 & 7.04 & 0.40 & 70.08 & 4.50 & 0.97 & 6.75 & 0.40 & 64.7 & 3.9 & - & & \\
\hline Boha \#2 & Pyroxene* & 5.0 & 0.6 & 0.33 & 0.01 & 6.23 & 0.37 & 136.60 & 9.90 & 0.97 & 6.20 & 0.37 & 59.4 & 3.5 & - & & \\
\hline Boha \#3 & Olivine* & 9.7 & 1.3 & 0.43 & 0.02 & 5.60 & 0.39 & 104.05 & 7.30 & 0.94 & 5.33 & 0.40 & 51.0 & 3.8 & 58.4 & 6.9 & 1.14 \\
\hline Gab-F \#1 & Olivine & 13.0 & 1.0 & 1.23 & 0.01 & 6.63 & 0.54 & 38.80 & 3.20 & 0.98 & 4.51 & 0.56 & 46.6 & 5.7 & - & & \\
\hline Gab-F \#2 & Olivine & 13.0 & 1.0 & 0.83 & 0.01 & 6.65 & 0.36 & 57.74 & 3.25 & 0.97 & 5.28 & 0.38 & 54.4 & 3.9 & - & & \\
\hline Gab-F \#3 & Olivine* & 13.0 & 1.0 & 0.92 & 0.01 & 6.42 & 0.34 & 50.26 & 2.76 & 0.97 & 4.87 & 0.36 & 50.3 & 3.7 & - & & \\
\hline Gab-F \#4 & Pyroxene & 13.0 & 1.0 & 4.05 & 0.01 & 12.73 & 0.72 & 22.66 & 1.30 & 0.98 & 5.60 & 0.90 & 57.8 & 9.0 & - & & \\
\hline Gab-F \#5 & Pyroxene & 13.0 & 1.0 & 0.95 & 0.003 & 6.08 & 0.32 & 46.14 & 2.40 & 0.98 & 4.51 & 0.34 & 46.5 & 3.5 & 51.1 & 5.0 & 1.12 \\
\hline Yem-6 \#1 & Pyroxene & 12.2 & 0.6 & 2.04 & 0.003 & 7.58 & 0.42 & 26.8 & 1.5 & 0.96 & 4.27 & 0.45 & 43.2 & 4.6 & - & & \\
\hline Yem-6 \#2 & $\begin{array}{l}\text { Olivine } \\
\text { onves }\end{array}$ & 12.2 & 0.6 & 2.23 & 0.67 & 4.40 & 0.29 & 142.2 & 43.7 & 0.97 & 4.15 & 0.31 & 42.0 & $\begin{array}{l}3.2 \\
3.2\end{array}$ & - & & \\
\hline Yem-6 \#3 & Olivine & 12.2 & 0.6 & 0.82 & 0.004 & 5.36 & 0.41 & 47.2 & 3.7 & 0.97 & 4.09 & 0.42 & 41.5 & 4.3 & 42.2 & 2.3 & 1.08 \\
\hline Bodo \#1 & Pyroxene & 9.9 & 1.3 & 1.34 & 0.134 & 5.46 & 0.43 & 29.3 & 3.7 & 0.97 & 3.72 & 0.53 & 36.9 & 5.3 & - & & \\
\hline Bodo \#2 & Pyroxene & 9.9 & 1.3 & 2.07 & 0.011 & 6.85 & 0.27 & 23.9 & 0.9 & 0.97 & 4.13 & 0.47 & 41.0 & 4.7 & - & & \\
\hline Bodo \#3 & Olivine & 9.9 & 1.3 & 3.43 & 0.004 & 8.12 & 0.43 & 17.1 & 0.9 & 0.98 & 3.48 & 0.77 & 34.6 & 7.6 & 37.5 & 3.5 & 1.08 \\
\hline Yem-1 \#1 & Pyroxene & 8.0 & 0.4 & 2.98 & 0.000 & 5.18 & 0.28 & 12.5 & 0.7 & 0.95 & 1.97 & 0.10 & 19.7 & 3.2 & - & & \\
\hline Yem-1 \#2 & Pyroxene & 8.0 & 0.4 & 4.21 & 0.001 & 7.02 & 0.38 & 12.0 & 0.7 & 0.95 & 2.47 & 0.12 & 24.7 & 4.4 & 22.2 & 3.5 & 1.03 \\
\hline Yem-10 & Olivine & $10.9^{*}$ & $2^{*}$ & 43.13 & 0.06 & 8.56 & 4.42 & 14.33 & 0.70 & 0.81 & 2.53 & 1.27 & 26.3 & 13.2 & 26.3 & 13.2 & 1.05 \\
\hline Gab-C3 \#1 & Pyroxene & $10.9^{*}$ & $2^{*}$ & 0.70 & 0.006 & 0.24 & 0.06 & 2.4 & 0.6 & 0.97 & -0.84 & 0.20 & -8.8 & -2.1 & $<2 \boldsymbol{k} a$ & & \\
\hline
\end{tabular}

a * indicates samples that were crushed before fusion in order to reduce the magmatic ${ }^{3} \mathrm{He}$ and ${ }^{4} \mathrm{He}$ contributions.

${ }^{\mathrm{b}}$ Magmatic ratios calculated from crush measurements (plain text) or by the isochron method (italic); see Supplementary Material 3 for more details.

${ }^{\mathrm{c}} \mathrm{R}$ factor calculated according to Blard and Farley, 2008. See Supplementary Material 4 for more details.

${ }^{\mathrm{d}}$ Minimum Surface Exposure Ages. Errors include the uncertainty of the analytical procedures, but do not include production rate or scaling factor errors.

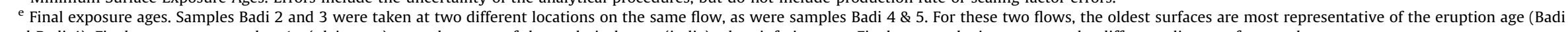
2 and Badi 4). Final errors correspond to $1 \sigma$ (plain text) or to the mean of the analytical error (italic) when inferior to $\sigma$. Final errors take into account the different aliquots of a sample.

f Paleomagnetic correction factor. This factor takes into account temporal variations in the paleomagnetic field. Based on the model of Dunai, 2001; using Carcaillet et al., 2004 database. 
unit and vents (Fig. 2) appears to be confined to the axial graben, suggesting it was erupted through fissures and sourced from segment-parallel dyke intrusions, similar to the activity observed from 2005 to 2010 (Wright et al., 2012).

The trachy-andesitic flow Boha was dated at $\mathbf{5 8 . 4} \pm 6.9$ ka.

\subsubsection{Off-axis Badi volcanism}

Following the emplacement of the previous flow fields, the next volcanic episode identified in our study area was the eruption of discrete basaltic lava flows from parasitic cones on the flanks of the off-axis Badi volcano, about $25 \mathrm{~km}$ west of the rift-axis (Fig. 1). Pairs of samples from two lava flows (BAD-2/3 and BAD-4/5) yield consistent surface exposure ages, constraining the eruption-ages of these lava flows to $\mathbf{5 4 . 9} \pm 3.6 \mathbf{k a}$ and $39.8 \pm 3.7 \mathrm{ka}$. Despite extensive occurrence of older off-axis volcanism west of Badi volcano (the Dabbayra chain), we believe that these monogenetic parasitic cones emplaced on the flanks of the volcano result from renewed injection of basaltic magma to this system, beginning around 55 kyrs ago with the eruption of relatively primitive melts ( $\mathrm{MgO}>8 \%$, Fig. 4 ).

\subsubsection{Southern Dabbahu central volcanism}

Chronologically, the next volcanic episode was the filling of the growing rift-axis graben by emplacement of porphyritic basaltic 'a'ā lava flows from Dabbahu. The thick ( 4-12 m) 'a'à lava flows appear to have been concentrated in the northern part of the axis, flowing down from the flanks of Dabbahu (Figs. 2 and 8). The minimum surface exposure ages of the first porphyritic lavas (which covered the Gab-D pāhoehoe basalts) range from $\mathbf{5 1 . 1} \pm 5.0$ to $\mathbf{4 2 . 2} \pm 2.3 \mathrm{ka}$ (GAB-F and YEM-4/6). The 37.5 \pm 3.5 ka exposure age of the lava flow sampled at Bodolita (BODO) suggests that this lava was emitted as part of the same volcanic episode, consistent with the spectral signature of the basalts at these two locations, as observed on ASTER data (Bodo was collected $\sim 6 \mathrm{~km}$ west of the mapped area illustrated in Fig. 2).

A successive phase of volcanism on the flanks of Dabbahu resulted in the more differentiated and less-phyric lavas (Fig. 4), also emitted from Dabbahu flank fissures. The exposure ages of samples Yem-10 and Yem-1 (26.3 $\pm 13.2 \mathrm{ka}$ and $22.2 \pm 3.5 \mathrm{ka}$ respectively) constrain the initial stages of emplacement of these lavas to around $\mathbf{2 5}$ ka (Figs. 2 and 8).

\subsubsection{Recent and historic activity}

Although Gab-C was analysed, there was insufficient ${ }^{3} \mathrm{He}_{c}$ in the sample to determine an age. Based on mass spectrometer detection limits, it is likely that this sample is younger than $2 \mathrm{ka}$. Field observation and satellite imagery (Fig. 1) indicate that this young, very dark fissure unit continues along the depression-axis as far as the middle of the segment, and is typical of recent eruptive activity in the rift axis, as observed in 2007, 2009 and 2010. In contrast to all the older samples analysed, the chemistry of this lava (Fig. 4) suggests that it was derived from the midsegment magma chamber (Ferguson et al., 2010) and not the Dabbahu magma reservoirs (Fig. 5).

\section{Discussion}

\subsection{Record of magma differentiation and variations in supply rate}

We define magmatic cycles as the time interval between two successive magma chamber replenishments. The start of a magmatic cycle is clearly marked by the dramatic change in composition resulting from the input of fresh, undifferentiated magma to reservoirs that have previously evolved. In the study area, we can directly observe the subsequent differentiation of the magma as a

\section{Construction of the Dabbahu central volcano and associated development of the rift axial depression}
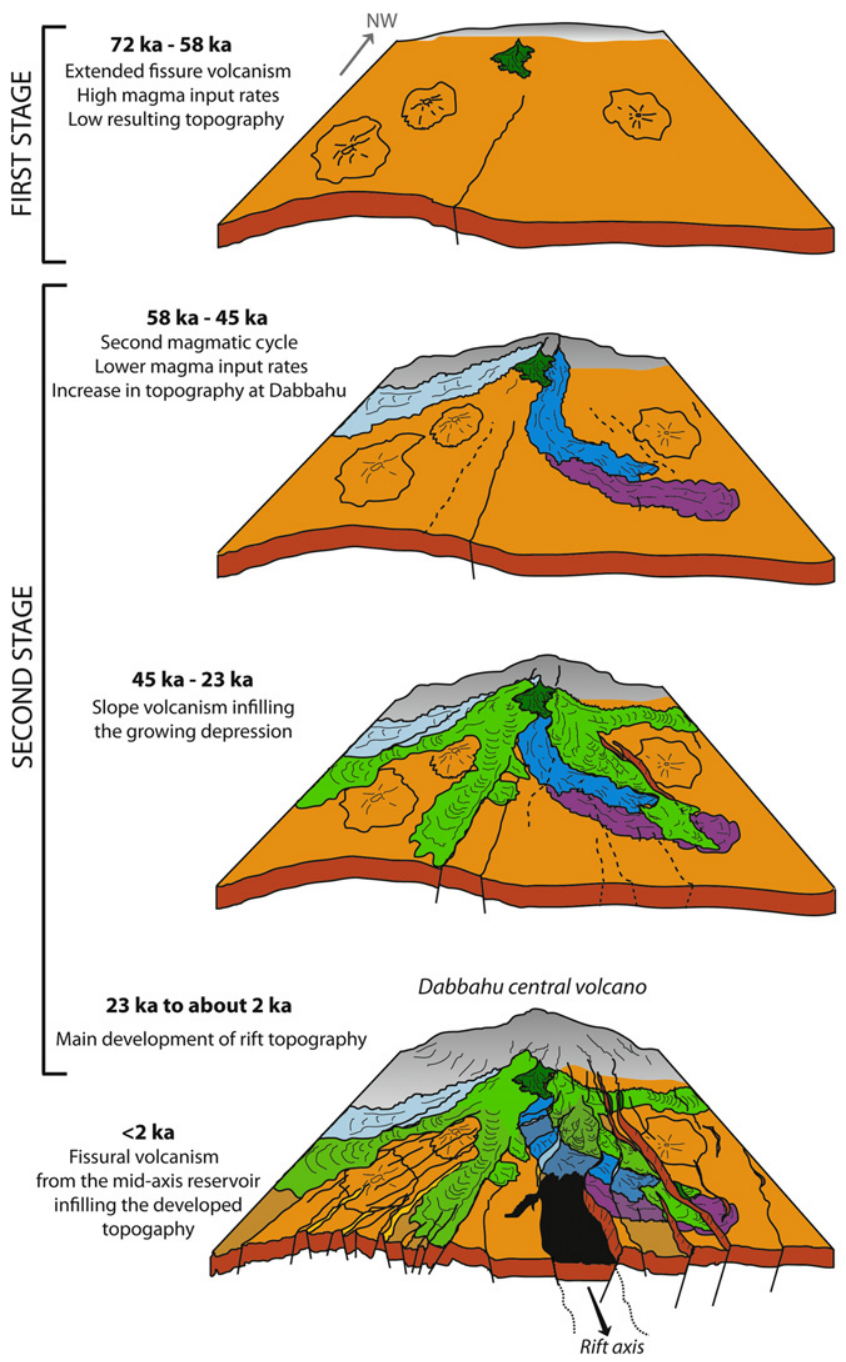

Fig. 8. Simplified summary sketch of the northern DMH morphological evolution The colour code is the same as for the geological map in Fig. 2. This evolution diagram illustrates the interplay and correlation between the two stages of the volcano construction and the two identified magmatic cycles from $72 \mathrm{ka}$ to the present.

function of time, through systematic changes in lava composition with age (Fig. 7). For example, at the rift-segment termination (Dabbahu) the oldest recorded units ( $72 \mathrm{ka}$ ) correspond to a series of high MgO, relatively high volume, pāhoehoe lava flows fed by fissure eruptions (orange unit in Figs. 2 and 8). The subsequent lavas (58 ka trachyandesites) have significantly lower $\mathrm{MgO}$ (5.0$1.33 \mathrm{wt} \%$ ), and are smaller and less numerous (Fig. 7). This discrete episode of more differentiated lavas was followed by a sudden return to $\mathrm{MgO}$ contents comparable to the earlier mafic phase ( $\sim-6 \mathrm{wt} \%)$ and the emission of a series of slope flows, radially emplaced on the southern flank of the nascent volcano between $51 \mathrm{ka}$ and $23 \mathrm{ka}$ (Fig. 8). Similarly, at Badi we observe an evolution from 8.37 to $6.74 \mathrm{wt} \% \mathrm{MgO}$ in $\sim 15 \mathrm{kyrs}$ (between 54 and $39 \mathrm{ka}$ ) where formation of the parasitic monogenetic cones appears to be coeval with on-going differentiation of the same batch of magma.

Overall, the pattern defined by the age/composition evolution of the erupted magmas (Fig. 7) suggests the existence of two distinct sequential differentiation events for this part of the Dabbahu volcano since about $70 \mathrm{ka}$. These cycles are clearly 
defined here because of the small spatial scale of our observations on the southern flank of Dabbahu (Fig. 2). On a larger scale (e.g. that of the entire Dabbahu volcano), it may be harder to decipher such well defined cycles, because of the complexity of the magmatic system and the geometry of the magma storagezones which may be divided into several shallow sill-like bodies at $1-5 \mathrm{~km}$ depth, as recently published by Field et al. (2012). In line with the proposed geometry for the Dabbahu plumbing system (Field et al., 2012), the two compositional cycles we document would correspond to the evolution of a single sill-like reservoir, and were coeval with two major phases of construction of this central volcano.

The first stage consisted of a spatially extensive fissure eruption episode that appears to have extended over the entire base of the volcano (Fig. 8), resulting from the arrival of a new batch of primitive melt at the base of the crust. We date the very last lavas produced by this episode at the top of the pāhoehoe flow field at $72-66 \mathrm{ka}$. However, this cycle probably started earlier ( $\sim 80$ 90 ka based on the duration of magmatic cycles at Dabbahu) with the emission of more primitive lavas at the base of the pile, such as those sampled by Barberi et al. (1974) with MgO contents of about $10 \mathrm{wt} \%$ (Fig. 4). In this scenario, during this first stage, massive transfer of basic magma through the upper crust from the deep (10-15 km, Field et al., 2013) main reservoir established the complex reservoir system of shallow sill-like bodies, in which the basic magmas continued to differentiate separately. The trachyandesitic composition we observe of lavas emplaced at about $59 \mathrm{ka}$, would then be the end product of one of the differentiation processes in a single sill-like reservoir.

In contrast, the volume of extruded lavas is lower for the 2nd stage. From the detailed map and from field observations of lava unit thicknesses, we can estimate the relative volumes of the two units (Fig. 2): the volume of the 2nd magmatic cycle is less than one-third of the first one. These younger radial lavas, emplaced on the growing slopes of the volcano (Fig. 8), correspond to a second phase of construction on the southern flank of the volcano. This is coeval with a new magmatic cycle (Fig. 7) following transfer of new, undifferentiated magma to one of the underlying shallow sill-like reservoirs (Field et al., 2012).

The chronological data we provide in this study constrain the total duration of this complete magmatic evolution (two magmatic cycles) to $70-80$ kyrs, given the uncertainty related to the initiation of fissure volcanism. This duration is considerably longer than that estimated for an arc volcano: at Merapi, Indonesia, for example, Gertisser and Keller (2003) documented the existence of two magmatic cycles in only $2000 \mathrm{yr}$, highlighting the complexity of differentiation and replenishment processes, and the need for high-quality chronological data in order to better understand these processes.

\subsection{Morphological evolution of the rift controlled by magma supply along the segment}

In addition to the temporal overlap between magmatic cycles and growth of the Dabbahu edifice described above, we also observe significant spatial overlap between the volcanic products of the Dabbahu central volcano and the axial depression of the neo-volcanic zone (Fig. 1). This spatial overlap was at a maximum during the first cycle of massive magma input when tectonic features of the rift were poorly expressed and the topography was subdued (Fig. 8). This first stage of rift construction resulted either from less-intensive faulting or from an eruption rate that was high enough to regularly resurface the neo-volcanic zone, making the interplay of faulting and lava-infilling difficult to assess here (Fig. 8). On the other hand, given that fissure volcanism fed by dykes reaching the surface is more likely to release tectonic strain
(Qin and Buck, 2008), a degree of feedback between fault activity and high fissure-eruption rates might also exist. Moreover, even if tectonic activity was not well expressed at around $70 \mathrm{ka}$ and the topography was subdued, it seems that this first magmatic phase was influenced by the regional tectonic regime, as shown by the $\mathrm{N}-\mathrm{S}$ alignment of eruptive centres close to Gab I (Fig. 2). This suggests that a large part of the extension in the northern $\mathrm{DMH}$ segment was accommodated during the first stage of riftconstruction by magma injection throughout the entire crust.

The initial phase of apparently subdued tectonic activity was followed by a second phase in which fault development was much more deeply expressed in the topography. During this second stage, defined from 58 ka to present, the Dabbahu volcanic edifice progressively grew with eruption of slope 'a'ā lava flows (Fig. 8) from a region higher up the flank of the volcano. During this stage, fault growth increased, and new (or reactivated) faults dissected the older pāhoehoe lavas, which were displaced vertically by more than $50 \mathrm{~m}$ on the eastern shoulder of the neovolcanic zone (Figs. 2 and 8 ). The oldest dated lava flow of the 2nd magmatic cycle (Gab-F, blue in Fig. 2) flowed oblique to the main rift direction and was not controlled by faulting during eruption at $51 \mathrm{ka}$. However, the emplacement of all younger units (2025 ka green in Fig. 2) was at least partly controlled by fault growth (Figs. 2 and 8), highlighting the progressive development of the present-day fault array and associated depression of the neo-volcanic zone during this second stage of construction.

Since $23 \mathrm{ka}$, apparently the northern part of the rift depression has no longer been filled with lavas erupted from Dabbahu (either because the melt pocket was not refilled, or because the most differentiated lavas, presumably more viscous, did not propagate to the sampled area-e.g. south of samples Yem 1 and 10) further favouring the expression of fault growth. The younger lavas recently emplaced at the rift axis (Gab C, Figs. 2 and 8) display the chemical signature of the mid-segment magma chamber and erupted from axial fissures.

\subsection{Contribution of the Dabbahu magmatic system in maintaining segment accretion}

It appears that an increase in tectonic activity and fault displacement after $51 \mathrm{ka}$ in the northern part of the segment (Fig. 8) may be linked to a decrease in magma supply rate (2nd cycle on Fig. 7), which in turn also controlled the topographic expression and preservation of the newly formed axial depression by limiting infilling and resurfacing (Fig. 8). Magma supply at Dabbahu should then be a dominant process on both the growth of the volcanic edifice, and on the expression of major faults south of the edifice along the neo-volcanic zone of the segment axis.

At least three different magmatic systems (of which two were still active in 2005) interact beneath this part of the segment: the Dabbahu volcano at the northern extremity of the segment, the off-axis Badi volcano, and the mid-segment magma chamber (MSMC) system (Fig. 1). The off-axis Badi and Dabbahu volcanoes appear to have been derived from the same degree of partial melting (Fig. 5). Either melting conditions are very similar for both volcanoes aligned along the transform zone (Fig. 1), or they share a common deep magma reservoir located at the base of the crust. The trace element signature of the mid-axis volcanism is on the other hand distinct from Dabbahu/Badi, suggesting that the degree of partial melting is greater beneath the mid-axis reservoir due to a shallower and longer melting column. A clear implication of this observation (Figs. 4 and 5) is that the southward limit of lavas originating from Dabbahu is about one-third of the segment length; conversely the northward extent of lavas originating from the MSMC reaches two-thirds of the segment. 
All the volcanics in the mapped region (Fig. 2) that were emplaced after $72 \mathrm{ka}$ are geochemically similar to the Dabbahu magmatic complex. The study area also corresponds to the northern limit of the very recent $(<2 \mathrm{ka}$; Gab-C) dark lavas originating from the MSMC (Figs. 1B and 2). It appears that few dykes originating from the MSMC erupted at the surface at this distal tip of the rift. During the 2006-2010 recent injection sequence only two dykes reached the required maximum dykelength of about $20 \mathrm{~km}$ (Keir et al., 2009; Grandin et al., 2010), but neither showed any surface expression. Most of the other dykes injected from the MSMC were shorter than $20 \mathrm{~km}$, which also corresponds to the maximum surface outcrop of these dark lavas (Fig. 1B).

It therefore seems that the northern part of the segment is dominated by magmatic activity from Dabbahu which consequently seems to play a major role in maintaining segmentation in the northern part of the rift. Episodic replenishment alternating with periods where this part of the segment is magma-starved produces the lava compositions observed. During periods of high magma supply rates, such as the 1 st magmatic cycle (72-58 ka), extension in the northern segment is accommodated by magma injection without a pronounced axial depression. In contrast, during episodes of low magma supply, volcanism is focused under the growing central volcano which then erupts more differentiated products. Consequently, this stage also corresponds to a greater topographical expression at the apex of the neovolcanic zone and a lower axial depression as observed along the East Pacific Ridge (MacDonald et al., 2001). This complex spatial and temporal influence of the magma pocket present at the extremity of the segment certainly controls the morphological, if not tectonic, variations along the rift segment.

\section{Conclusions}

Cosmogenic ${ }^{3} \mathrm{He}$ surface exposure dating of basaltic lava flows, combined with field observations, geological mapping and geochemistry, unravel the volcano-magmatic history of the Dabbahu central volcano and its interactions with the DMH rift segment during the last $\sim 80-\mathrm{kyr}$. We show that

(1) The ages of various lava units allow us to distinguish distinct magmatic cycles each of 20-40 kyr duration, which correspond to periods of high and low magma supply rate. The repetition of these magma input/starvation phases contributed to the development of the Dabbahu central volcano.

(2) Variations in magma supply rate at the segment tip (e.g. beneath the Dabbahu volcano) strongly affect the development of the rift depression: when the system is well-supplied in magma, the morphological representation of any fault activity is limited (from 72 to $58 \mathrm{ka}$ ), whereas episodes of limited magma supply (from 51 ka to present) correlate with increases in topographic expression of any tectonic activity.

(3) Three different magma reservoirs operate in this segment. The Dabbahu and Badi volcanoes share the chemical composition of the DMH segment terminating transform zone, and are distinct from the most recent magma reservoir corresponding to the MSMC. Currently, the mid-segment reservoir feeds the neo-volcanic zone. The distinct chemical signatures between Dabbahu and the MSMC allow their respective contributions towards maintaining magmatic accretion to be estimated. It appears that the Dabbahu source contributes magma to around one-third of this portion of the segment. The remaining two-thirds are supplied from the MSMC. Second order magma chambers at the apex of a segment can produce at least a third of segment accretion through injection of magma at the apex of the segment.

\section{Acknowledgements}

This paper is dedicated to the memory of Osman Mohammed Tajuddin. For their help in the field, we thank J. Foeken, Y. Marrocchi and P. Lahitte, as well as the members of the Afar regional government at Semera. We are grateful to B. Tibari (CRPG) for assistance with cosmogenic ${ }^{3} \mathrm{He}$ and $U$ and Th measurements and L. Zimmerman (CRPG) for technical assistance with mass spectrometry. We thank L. Field and R. Grandin for fruitful discussions and M. Kurz and an anonymous reviewer for constructive and helpful reviews. Financial support was provided by the INSU "Actions Marges" consortium (RP\& SM) and the CRONUS-EU research training network: EU FP6 Marie Curie Actions, Project 511927 (AW post-doctoral position). C.V.-B. publishes with the permission of the Executive Director of the British Geological Survey (Natural Environment Research Council). This is CRPG Contribution no. 2238.

\section{Appendix A. Supporting information}

Supplementary data associated with this article can be found in the online version at http://dx.doi.org/10.1016/j.epsl.2013.02. 006 .

\section{References}

Ayele, A., Stuart, G., Bastow, I., Keir., D., 2007. The August 2002 earthquake sequence in north Afar: insights into the neotectonics of the Danakil microplate. J. Afr Earth Sci 48, 70-79.

Ayele, A. et al., 2009. September 2005 mega-dike emplacement in the MandaHarraro nascent oceanic rift (Afar depression). Geophys. Res. Lett. 36, L20306, http://dx.doi.org/10.1029/2009GL039605.

Ayalew, D., Ebinger, C., Bourdon, E., Wolfenden, E., Yirgu, G., Grassineau, N., 2006. Temporal compositional variation of early syn-rift rhyolites along the western Red Sea margin and northern Main Ethiopian rift. In: The Afar Volcanic Province within the East African Rift System. Geological Society, London, Special Publications, vol. 259, pp. 121-130.

Ayalew, D., Barbey, P., Marty, B., Reisberg, L., Yirgu, G., Pik, R., 2002. Source, genesis and timing of giant ignimbrite deposits associated with Ethiopian continental flood basalts. Geochim. Cosmochim. Acta 66, 1429-1448.

Barberi, F., Tazieff, H., Varet, J., 1974. Volcanism in the Afar depression: its tectonic and magmatic significance. Tectonophysics 15, 19-29.

Barisin, I., et al., 2009. Surface displacements in the September 2005 Afar rifting event from satellite image matching: asymmetric uplift and faulting. Geophys. Res. Lett. 36, 7.

Bastow, I.D., Keir, D., 2011. The protracted development of the continent-ocean transition in Afar. Nat. Geosci. 4, 248-250.

Bastow, I.D., et al., 2010. Melt-induced seismic anisotropy and magma assisted rifting in Ethiopia: evidence from surface waves. Geochem. Geophys. Geosyst. 11, 6 .

Bastow, I.D., Nyblade, A.A., Stuart, G.W., Rooney, T.O., Benoit, M.H., 2008. Upper mantle seismic structure beneath the Ethiopian hot spot: rifting at the edge of the African low-velocity anomaly. Geochem. Geophys. Geosyst. 9, Q12022, http://dx.doi.org/10.1029/2008GC002107.

Batiza, R., Becker, N., Bercovici, D., Coleman, T., Gorman, T., Head, J.W., Holloway, L., Karsten, J., Kelly., A., Keszthelyi, L.P., Maicher, D., Mueller, W., Muller, J., Norby, L., Paduan, J., Parker, G., Prockter, L., Stakes, D., White, J., 1996. New evidence from Alvin for the origin of deep-sea eruptive hyaloclastite on Seamount 6: Cocos plate $12^{\circ} 43^{\prime} \mathrm{N}$. Eos 77,319 .

Belachew, M., Ebinger, C., Coté, D., Keir, D., Rowland, J.V., Hammond, J.O.S., Ayele, A., 2011. Comparison of dike intrusions in an incipient seafloor-spreading segment in Afar, Ethiopia: seismicity perspectives. J. Geophys. Res. 116 B06405.

Blard, P.H., Farley, K.A., 2008. The influence of radiogenic ${ }^{4} \mathrm{He}$ on cosmogenic ${ }^{3} \mathrm{He}$ determinations in volcanic olivine and pyroxene. Earth Planet. Sci. Lett 276 20-29.

Blard, P.-H., Lavé, J., Pik, R., Quidelleur, X., Bourlès, D., Kieffer, G., 2005. Fossil cosmogenic ${ }^{3} \mathrm{He}$ record from $\mathrm{K} / \mathrm{Ar}$ dated basaltic flows of Mount Etna volcano 
(Sicily, $38^{\circ} \mathrm{N}$ ): Evaluation of a new paleoaltimeter. Earth Planet. Sci. Lett. 236 613-631.

Carbotte, S.M., Small, C., Donnelly, K., 2004. The influence of ridge migration on the magmatic segmentation of mid-ocean ridges. Nature 429, 743-746.

Carcaillet, J.T., Bourles, D.L., Thouveny, N., 2004. Geomagnetic dipole moment and ${ }^{10} \mathrm{Be}$ production rate intercalibration from authigenic ${ }^{10} \mathrm{Be} /{ }^{9} \mathrm{Be}$ for the last 1.3Ma. Geochem. Geophys. Geosyst. 5

Colman, A., et al., 2012. Effects of variable magma supply on mid-ocean ridge eruptions: constraints from mapped lava flow fields along the Galápagos Spreading Center. Geochem. Geophys. Geosyst.

Dunai, T.J., 2010. Cosmogenic Nuclides. Principles, Concepts and Application in the Earth Surface Sciences. Cambridge University Press, UK.

Dunai, T.J., 2001. Influence of secular variation of the geomagnetic field on production rates of in-situ produced cosmogenic nuclides. Earth Planet. Sci. Lett. 193, 203-218.

Ebinger, C.J., Casey, M., 2001. Continental breakup in magmatic provinces: an Ethiopian example. Geology 29, 527-530.

Ebinger, C., Ayele, A., Keir, D., Rowland, J., Yirgu, G., Wright, T., Belachew, M. Hamling, I., 2010. Length and timescales of rift faulting and magma intrusion: the Afar Rifting Cycle from 2005 to present. Annu. Rev. Earth Planet. Sci. 38 439-466.

Fenton, C.R., Niedermann, S., Goethals, M.M., Schneider, B., Wijbrans, J., 2009 Evaluation of cosmogenic ${ }^{3} \mathrm{He}$ and ${ }^{21} \mathrm{Ne}$ production rates in olivine and pyroxene from two Pleistocene basalt flows, western Grand Canyon, AZ USA. Quat. Geochronol. 4, 475-492.

Ferguson, D.J., Calvert, A.T., Pyle, D.M., Blundy, J.D., Yirgu, G., Wright, T.J., 2013. Constraining timescales of focused magmatic accretion and extension in the Afar crust using lava geochronology. Nat. Commun. 4, 1416, http://dx.doi.org/ $10.1038 /$ ncomms2410.

Ferguson, D.J., Barnie, T.D., Pyle, D.M., Oppenheimer, C., Yirgu, G., Lewi, E., Kidane T., Carn, S., Hamling, I.G., 2010. Recent rift-related volcanism in Afar, Ethiopia. Earth Planet. Sci. Lett. 292, 409-418.

Field, L., Blundy, J., Calvert, A., Yirgu, G., 2012. Magma storage conditions beneath Dabbahu Volcano (Ethiopia) constrained by petrology, seismicity and satellite geodesy. Bull. Volcanol., 1-24.

Field, L., et al., 2013. Magmatic history of Dabbahu, a composite volcano in the Afar Rift, Ethiopia. Geol. Soc. Am. Bull 125, 128-147.

Foeken, J.P.T., Day, S., Stuart, F.M., 2009. Cosmogenic ${ }^{3}$ He exposure dating of the Quaternary basalts from Fogo, Cape Verdes: implications for rift zone and magmatic reorganisation. Quat. Geochronol. 4, 37-49.

Gertisser, R., Keller, J., 2003. Temporal variations in magma composition at Merapi Volcano (Central Java, Indonesia): magmatic cycles during the past 2000 years of explosive activity. J. Volcanol. Geotherm. Res. 123 (1-2), 1-23.

Geoffroy, L., 2005. Volcanic passive margins. C. R. Geosci. 337 (16), 1395-1408.

Goehring, B.M., Kurz, M.D., Balco, G., Schaefer, J.M., Licciardi, J., Lifton, N., 2010. reevaluation of in situ cosmogenic ${ }^{3} \mathrm{He}$ production rates. Quat. Geochronol. 5 410-418.

Gosse, J.C., Phillips, F.M., 2001. Terrestrial in situ cosmogenic nuclides: theory and application. Quat. Sci. Rev. 20, 1475-1560.

Grandin, R., Socquet, A., Jacques, E., Mazzoni, N., de Chabalier, J.-B., King, G.C.P., 2010. Sequence of rifting in Afar, Manda-Hararo rift, Ethiopia, 2005-2009: Time-space evolution and interactions between dykes from interferometric synthetic aperture radar and static stress change modeling. J. Geophys. Res. 115, B10413.

Grandin, R., Socquet, A., Binet, R., Klinger, Y., Jacques, E., de Chabalier, J.-B., King, G.C.P. Lasserre, C., Tait, S., Tapponnier, P., Delorme, A., Pinzuti, P., 2009. Septembe 2005 MandaHararo-Dabbahu rifting event, Afar (Ethiopia): Constraints provided by geodetic data. J. Geophys. Res. 114, B08404.

Hammond, JOS et al, 2012. The nature of the crust beneath the Afar triple junction: evidence from receiver functions. Geochem. Geophys. Geosyst. 12, 12

Hammond, J.O.S., Kendall, J.-M., Stuart, G., Keir, D., Ebinger, C., Ayele, A., Belachew, M. 2011. The nature of the crust beneath the Afar triple junction: evidence from receiver functions. Geochem. Geophys. Geosyst. 12, Q12004.

Hayward, N.J., Ebinger, C.J., 1996. Variations in the along-axis segmentation of the Afar Rift system. Tectonics 15, 244-257.

Hamling, I.J., Bennati, A., Calais, L., Ebinger, C., Keir, D., Lewi, E., Wright, T.J., Yirgu, G., 2009. Geodetic observations on the ongoing Dabbahu rifting episode: new dyke intrusions in 2006 and 2007. Geophys. J. Int. 78, 989-1003.

Hofmann, C. Courtillot, V., Feraud, G., Rochette, P., Yirgu, G., Ketefo, E., Pik, R. 1997. Timing of the Ethiopian flood basalt event and implications for plume birth and global change. Nature 389, 838-841.

Keir, D., et al., 2011. Mapping the evolving strain field during continental breakup from crustal anisotropy in the Afar Depression. Nat. Commun. 2, 285.

Keir, D.H., Ayele, I.J., Calais, E., Ebinger, C., Wright, T., Jacques, E., Mohamed, K. Hammond, J.O.S., Belachew, M., Baker, E., Rowland, J., Lewi, E. Bennati, L., 2009. Evidence for focused magmatic accretion at segment centers from lateral dyke injections captured beneath the Red Sea rift in Afar. Geology 37, 59-62.

Kurz, M.D., Geist, D., 1999. Dynamics of the Galapagos hotspot from helium isotope geochemistry. Geochim. Cosmochim. Acta 63 (23-24), 4139-4156.

Kurz, M.D., et al., 1990. Cosmic ray exposure dating with in situ produced cosmogenic ${ }^{3} \mathrm{He}$ : results from young Hawaiian lava flows. Earth Planet. Sci. Lett. 97 (1-2), 177-189.

Kurz, M.D., 1986. In situ production of terrestrial cosmogenic helium and some applications to geochronology. Geochim. Cosmochim. Acta 50, 2855-2862.
Lahitte, P., Gillot, P.-Y., Courtillot, V., 2003a. Silicic central volcanoes as precursors to rift propagation: the Afar case. Earth Planet. Sci. Lett. 207, 103-116.

Lahitte, P., Gillot, P.-Y., Kidane, T., Courtillot, V., Bekele, A., 2003b. New age constraints on the timing of volcanism in central Afar, in the presence of propagating rifts. J. Geophys. Res 108, 2123.

Lal, D., 1991. Cosmic ray labeling of erosion surfaces: in situ nuclide production rates and erosion models. Earth Planet. Sci. Lett. 104, 424-439.

Macdonald, K.C., et al., 2001. Mid-Ocean Ridge Tectonics, Volcanism, and Geomorphology, Encyclopedia of Ocean Sciences, Second Edition Academic Press, Oxford, p. 852-866.

Macdonald, K.C., 1982. Mid-ocean ridges: fine-scale tectonic, volcanic and hydrothermal processes. Annu. Rev. Earth Planet. Sci. 10, 155-190.

Makris, J., Ginzburg, A., 1987. The Afar Depression: transition between continental rifting and sea-floor spreading. Tectonophysics 141 (1-3), 199-214.

Margerison, H.R., Phillips, W.M., Stuart, F.M., Sugden, D.E., 2004. Cosmogenic ${ }^{3} \mathrm{He}$ concentrations in ancient flood deposits from the Coombs Hills, northern Dry Valleys, East Antarctica: interpreting exposure ages and erosion rates. Earth Planet. Sci. Lett. 230, 163-175.

Marty, B., Pik, R., Yirgu, G., 1996. Helium isotopic variations in Ethiopian Plume Lavas: nature of magmatic sources and limit on lower mantle contribution. Earth Planet. Sci. Lett. 144, 223-237.

Matsuda, J., Matsumoto, T., Sumino, H., Nagao, K., Yamamoto, J., Miwa, Y., Kaneoka, I., Takahata, Sano, Y., 2002. The ${ }^{3} \mathrm{He} /{ }^{4} \mathrm{He}$ ratio of the newinternal He Standard of Japan (HESJ). Geochem. J. 36, 191-195.

Mohr, P.A., 1967. Major volcano-tectonic lineament in the Ethiopian rift system. Nature 213 (5077), 664-665.

Niedermann, S., 2002. Cosmic-ray-produced noble gases in terrestrial rocks: dating tools for surface processes. In: Porcelli, D., Ballentine, C.J., Wieler, R. (Eds.). Noble gases in geochemistry and cosmochemistry. Rev. Mineral. Geochem. 47, 731-784.

Perfit, M.R. and W.W. Chadwick, Jr., Magmatism at mid-ocean ridges: constraints from volcanological and geochemical investigations. In: Faulting and Magmatism at Mid-Ocean Ridges. 1998, AGU: Washington, DC. p. 59-115.

Pik, R., Deniel, C., Coulon, C., Yirgu, G., Marty, B., 1999. Isotopic and trace element signatures of Ethiopian flood basalts: evidence for plume/lithosphere interactions. Geochim. Cosmochim. Acta 63, 2263-2279.

Pik, R., Marty, B., Hilton, D.R., 2006. How many mantle plumes in Africa? the geochemical point of view. Chem. Geol. 226, 100-114.

Pik, R., Deniel, C., Coulon, C., Yirgu, G., Hofmann, C., Dereje, A., 1998. The Northwestern Ethiopian Plateau flood basalts: classification and spatial distribution of magma types. J. Volcanol. Geotherm. Res. 81, 91-111.

Qin, R., Buck, W.R., 2008. Why meter-wide dykes at oceanic spreading centers? Earth Planet. Sci. Lett. 265, 466-474.

Rooney, T.O., et al., 2012. Geochemical evidence of mantle reservoir evolution during progressive rifting along the western Afar margin. Geochim. Cosmochim. Acta $102(0), 65-88$

Rowland, J., Baker, E., Ebinger, C.J., Keir, D., Kidane, T., Biggs, J., Hayward, N., Wright, T.J., 2007. Fault growth at a nascent slow-spreading ridge: 2005 Dabbahu rifting episode, Afar. Geophys. J. Int. 171, 1226-1246.

Schimmelpfennig, I., Benedetti, L., Garreta, V., Pik, R., Blard, P.H., Burnard, P.G., Bourlès, D.L., Finkel, R., Ammon, K., Dunai, T., 2011a. Calibration of cosmogenic ${ }^{36} \mathrm{Cl}$ production rates by spallation of $\mathrm{Ca}$ and $\mathrm{K}$ on in lava flows samples from Mt. Etna $\left(38^{\circ} \mathrm{N}\right.$, Italy) and PayunMatru (36 S, Argentina). Geochim. Cosmochim. Acta 75, 2611-2632.

Schimmelpfennig, I., Williams, A., Pik, R., Burnard, P., Niedermann, S., Finkel, R., Schneider, B., Benedetti, L., 2011b. Inter-comparison of cosmogenic in-situ ${ }^{3} \mathrm{He},{ }^{21} \mathrm{Ne}$ and ${ }^{36} \mathrm{Cl}$ at low latitude along an altitude transect on the SE slope of Kilimanjaro volcano ( $3^{\circ}$ S, Tanzania). Quat. Geochronol. 6, 425-436.

Stone, J.O., 2000. Air pressure and cosmogenic isotope production. J. Geophys. Res. 105, 23753-23759.

Sun, S.S., McDonough, W.F., 1989. Chemical and Isotopic Systematics of oceanic basalts: implications for mantle composition and processes. In: Saunders, A.D., Norry, M.J. (Eds.). Magmatism in the Ocean Basins. Geological Society, London, Special Publications. vol. 42, pp. 313-345.

Tiberi, C., Ebinger, C., Ballu, V., Stuart, G., Oluma, B., 2005. Inverse model of gravity data from the Red Sea-Aden-East African rifts triple junction zone. Geophys. J. Int. 163.

Vermeesch, P., 2007. CosmoCalc: An Excel add-in for cosmogenic nuclide calculations. Geochem. Geophys. Geosyst. 8, Q08003.

Vye-Brown, C.L., Smith, K., Medynski, S., Field, L., Wright, T., 2012 Geological map of the Dabbahu (Manda-Hararo) Rift, 1:100,000 scale, British Geological Survey.

Vye, C.L., Napier, B., Smith, K., Medynski, S., Loughlin, S., 2011. Identification and characterization of eruption sites and lava flows within the Manda-Hararo rift segment, Afar Depression, Ethiopia. American Geophysical Union, Fall Meeting 2011, abstract \#V13C-2610.

Wolfenden, E., Ebinger, C., Yirgu, G., Renne, P.R, Kelley, S.P., 2005. Evolution of a volcanic rifted margin; southern Red Sea, Ethiopia. Geol. Soc. Am. Bull. 117, 846-864.

Workman, R.K., Hart, S.R., 2005. Major and trace element composition of the depleted MORB mantle (DMM). Earth Planet. Sci. Lett. 231, 53-72.

Wright, T.J., et al., 2012. Geophysical constraints on the dynamics of spreading centres from rifting episodes on land. Nat. Geosci. 5 (4), 242-250.

Wright, T., Ebinger, C., Biggs, J., Ayele, A., Yirgu, G., Keir, D., Stork, A., 2006. Magmamaintained rift segmentation at continental rupture in the 2005 Afar dyking episode. Nature 442, 291-294. 